\title{
Pre-clinical investigations of $\beta$-carboline alkaloids as antidepressant agents: a systematic review
}

Christiane Adrielly Alves Ferraz ${ }^{1}$, Raimundo Gonçalves de Oliveira Júnior ${ }^{2}$, Laurent Picot $^{2}$, Jackson Roberto Guedes da Silva Almeida ${ }^{1}$, Xirley Pereira Nunes ${ }^{1 *}$

${ }^{1}$ Núcleo de Estudos e Pesquisas de Plantas Medicinais (NEPLAME), Universidade Federal do Vale do São Francisco, 56304-917 Petrolina, Brazil.

${ }^{2}$ Littoral Environnement et Sociétés (LIENSs), UMRi CNRS 7266, Université de La Rochelle, 17042 La Rochelle, France.

${ }^{*}$ Corresponding author at: NEPLAME, Universidade Federal do Vale do São Francisco. Av. José de Sá Maniçoba, S/N - Centro, Petrolina-PE, 56304-917, Brazil. E-mail address: xirleypn2@gmail.com 


\section{ABSTRACT}

Depressive disorders remain a current public health problem whose prevalence has increased in the past decades. In the constant search for new therapeutic alternatives, $\beta$ carboline alkaloids have been identified as good candidates for new antidepressant drugs. In this systematic review, we summarized all pre-clinical investigations involving the use of natural or semisynthetic $\beta$-carboline in depression models. A literature search was conducted in August 2018, using PubMed, Scopus and Science Direct databases. All reports were carefully analyzed, and data extraction was conducted through standardized forms. Methodological quality assessment of in vivo studies was also performed. The entire systematic review was performed according to PRISMA statement. From a total of 373 articles, 26 met all inclusion criteria. In vitro and in vivo studies have evaluated a wide variety of $\beta$-carbolines through enzymatic and binding assays, and acute or chronic animal models. Most of the in vivo and in vitro studies is concentrated on two molecules: harman and harmine. They have been investigated in several animal models and some mechanisms of action have been proposed for their antidepressant activity. In general, $\beta$ carbolines modulate 5-HT and GABA systems, promote neurogenesis, induce neuroendocrine response and restore astrocytic function, being effective when administrated acutely or chronically in different animal models, including chronic mild stress protocols. In short, $\beta$-carbolines are multi-target antidepressant compounds and may be useful in the treatment of depressive disorders.

Keywords: $\beta$-carboline; alkaloids; depression; monoamine oxidase; serotonin. 


\section{Abbreviations}

5-HT (serotonin)

AAT (active avoidance test)

ACh (acetylcholine)

$\mathrm{BC}$ (fully aromatic $\beta$-carbolines)

BZ (benzodiazepine)

CMS (chronic mild stress)

CNS (central nervous system)

CUS (chronic unpredictable stress)

DA (dopamine)

DHBC (dihydro- $\beta$-carbolines)

DMCM (6,7-dimethoxy-4-ethyl- $\beta$-carboline methyl ester)

EPM (elevated plus-maze test)

FST (forced swimming test)

GABA (gamma-aminobutyric acid)

GFAP (glial fibrillary acidic protein)

GLT-1 (glutamate transporter-1)

Iba-1 (ionizing calcium-binding adaptor molecule 1)

$\mathrm{IC}_{50}$ (half maximal inhibitory concentration)

$\mathrm{K}_{\mathrm{i}}$ (inhibition constant)

MAO (monoamine oxidase)

NA (noradrenaline)

OFT (open field test)

THBC (tetrahydro- $\beta$-carbolines)

TST (tail suspension test) 
$\beta$-CCM ( $\beta$-carboline-3-carboxylic acid methyl ester)

$\beta$-CCT ( $\beta$-carboline-3-carboxylate- $t$-butyl ester)

\section{Highlights}

- A variety of $\beta$-carbolines has been investigated for antidepressant purposes.

- A large part of the in vivo and in vitro studies is concentrated on two molecules (harman and harmine).

- $\quad \beta$-carbolines modulate 5-HT and GABA systems, promote neurogenesis, induce neuroendocrine response and restore astrocytic function.

- $\beta$-carbolines are multi-target drugs and may be useful in the treatment of depressive disorders.

\section{Introduction}

Depressive disorders consist of emotional and mood deregulation and may range from dysthymia, a chronic low mood syndrome, to major depression, usually associated with other mental disorders such as anxiety, insomnia, social phobia and compulsive behaviors [1,2]. Although discussed for a long time, depression remains a current public health problem whose prevalence has increased in recent decades. In general, its lifetime prevalence rates range for most countries from 8 to $12 \%$ affecting both emerging and developed nations, regardless of age, ethnicity or social status [2-6].

The underlying pathophysiology of depression is not completely understood, but several reports show that genetic, physiological, psychological and social factors may play an important role in its development. Recent studies have pointed to various new hypotheses justifying depressive symptoms, including neuroendocrine response, involvement of pro-inflammatory cytokines, and dysfunction of glutamate and GABA 
(gamma-aminobutyric acid) neurotransmissions [2,7,8]. However, the monoamine hypothesis, which describes a relevant deficiency of serotonin (5-HT), dopamine (DA) and/or noradrenaline (NA) in the central nervous system (CNS), is still leading to clinical trials of new antidepressant drugs $[6,8,9]$. In fact, most of the currently available antidepressants act on one or more mechanisms compatible with the monoamine hypothesis: a) inhibition of monoamine reuptake; b) antagonism of inhibitory presynaptic monoamine receptors; c) monoamine oxidases (MAO) inhibition, enzymes responsible for the degradation of monoamines in the synaptic cleft. All these molecular mechanisms result in increased neurotransmission of monoamines, alleviating the typical symptoms of depression as shown in previous clinical studies [8,10-13].

In the last decades, the antidepressant potential of $\beta$-carboline alkaloids has been investigated due to their actions on the monoamine neurotransmission, especially the serotoninergic system [14-16]. $\beta$-carbolines are a large group of natural indole alkaloids presenting a common tricyclic pyrido-3,4-indole ring, similar to the tryptamine structure. They can be categorized according to the saturation of their N-containing six-membered ring: a) unsaturated members are named as fully aromatic $\beta$-carbolines $(\mathrm{BC})$; b) partially saturated members are named dihydro- $\beta$-carbolines (DHBC); c) and completely saturated member are known as tetrahydro- $\beta$-carbolines (THBC) (Fig. 1) [16,17].

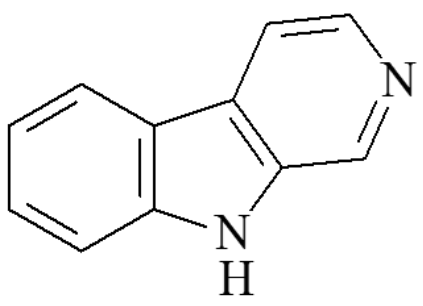

BC

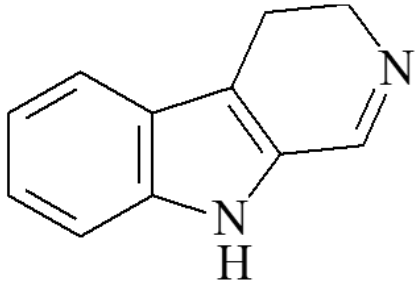

DHBC

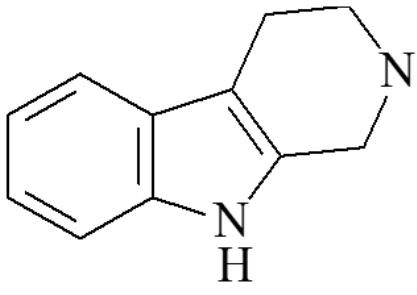

THBC

Fig. 1. Chemical classification of $\beta$-carboline alkaloids: fully aromatic $\beta$-carbolines (BC), dihydro- $\beta$-carbolines (DHBC) and tetrahydro- $\beta$-carboline (THBC). 
$\beta$-carbolines were originally found in Peganum harmala, a traditional medicinal plant distributed in Central Asia, Africa and South America. The $\beta$-carbolines harman, norharman and harmine, first isolated from P. harmala [16-18], and other $\beta$-carboline derivatives are widely found in medicinal plants [19-21], plant-derived foods (e.g. rice, wheat, soybeans, wine, coffee, grapes) $[22,23]$ and plant-derived inhaled substances such as tobacco [24]. In addition, Amazonian psychoactive plants containing high amounts of $\beta$-carbolines are often used in the preparation of hallucinogenic beverages, such as Ayahuasca, also known as natema, hoasca, daime, yagé, or yajé. Ayahuasca has been used in religious, initiation and curative rituals, especially in Brazil, Ecuador, Columbia and Peru [19]. Preliminary clinical trials have reported its antidepressant effect in patients with recurrent depression. This therapeutic response has been attributed to the presence of dimethyltryptamine (DMT) and the $\beta$-carbolines harmine and tetrahydroharmine, which may act synergistically $[25,26]$.

Previous in vitro and in vivo investigations also reported the antidepressant potential of isolated $\beta$-carbolines [27-29]. In this systematic review, we summarize and analyze all pre-clinical evidences involving the use of natural or semisynthetic $\beta$ carbolines in different experimental models. The main mechanisms of action involved in their antidepressant effect are also discussed in detail.

\section{Methods}

\subsection{Search strategy}

A systematic review was performed according to the Preferred Reporting Items for Systematic Reviews and Meta-Analyses (PRISMA) [30] statement in order to select 
all relevant articles published up to August 2018. An exhaustive literature search was performed in PubMed, Scopus and Science Direct databases, using a combination of the terms (beta-carboline, carboline or $\beta$-carboline) AND (depression, depression disorders or antidepressant). We did not contact investigators and we did not attempt to identify unpublished data.

\subsection{Study selection}

Manuscript selection was based on the following inclusion criteria: 1) articles published in English; 2) articles with search terms present in the title or abstract; and 3) pre-clinical (in vitro or in vivo) reports involving the use of natural or semisynthetic $\beta$ carboline alkaloids in experimental models for antidepressant activity assessment. Abstracts, conferences, editorials, book chapters, review articles, case reports, articles unavailable for download, or papers that did not directly involve the use of $\beta$-carboline alkaloids in experimental models of depression were excluded. Studies involving only pharmacological evaluation of plant-derived extracts or fractions containing $\beta$-carboline alkaloids were also excluded. Two independent investigators (CAAF and RGOJ) first selected the articles according to the title, then to the abstract and finally through a fulltext analysis. A third independent investigator (XPN) was consulted for possible disagreements. A careful revision was applied on all selected studies to identify and exclude any report that did not fit the inclusion criteria described above. Additional papers were included in this review after the analysis of all references from the selected studies.

\subsection{Data extraction and processing}

Data were collected into pre-defined standardized forms containing article information (first author, year and study location), methods (tested compounds, 
experimental protocols, animal models, doses or concentrations, route of administration, frequency of treatment) and results (main outcomes and mechanisms of action assessed). Abstracts of in vitro and in vivo studies were copied to separate files and then word clouds were elaborated using a free online word cloud generator (www.wordclouds.com). A study location map was elaborated using a free interactive map generator (www.mapinseconds.com). All other data was processed using Microsoft Office Excel ${ }^{\circledR}$ software.

\subsection{Methodological quality assessment}

The methodological quality of in vivo studies were evaluated using a checklist adapted from previous reports [31,32]. All selected articles were examined regarding the randomization of the treatment allocation, blinded drug administration, blinded outcome assessment, outcome measurements and appropriate statistical analysis. Studies that reported randomization of animals, blinding and outcome measurements were considered of higher methodological quality.

\section{Results and Discussion}

\subsection{Overall results}

In the initial search, 373 reports were identified (46 from Science Direct, 69 from PubMed and 258 from Scopus). Nevertheless, 108 articles were indexed in two or more databases and were considered only once, resulting in 265 original studies for general analysis. After reading titles and abstracts, and assessing the inclusion and exclusion criteria, 29 articles were selected for full-text analysis. Among them, 07 reports were excluded because they did not meet all inclusion criteria. Finally, a detailed analysis of 
the references list from all selected studies was performed, leading to the addition of 04 other pertinent reports that met all inclusion criteria after title, abstract and full-text analysis. In total, 26 studies were included for data extraction and processing. Fig. 2 shows a flowchart illustrating the entire study selection process used in this review.

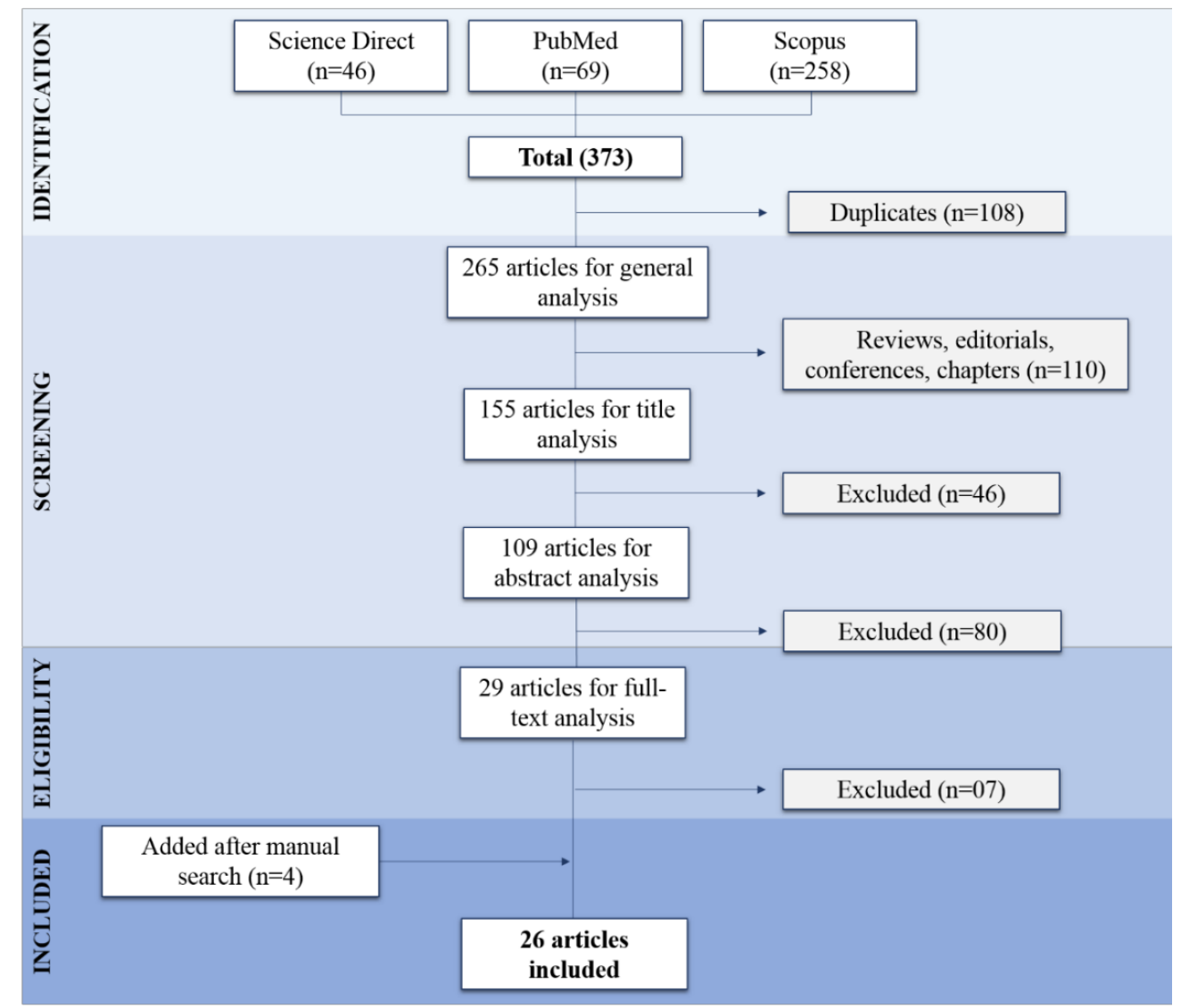

Fig. 2. Flowchart detailing literature search in this systematic review, in accordance with PRISMA statement.

All included articles were categorically analyzed in relation to study location, year of publication, $\beta$-carbolines investigated, experimental protocols and main outcomes, including relevant information about molecular targets. In general, most of investigations were authored by researchers from Spain (07 reports, 27\%), USA (06 reports, 23\%) and Brazil (03 reports, 11.5\%), as shown in Fig. 3. This may be related to the geographical 
distribution of species containing high $\beta$-carboline content, such as Banisteriopsis caapi (Malpighiaceae) and P. harmala L. (Zygophyllaceae), which exhibit psychoactive actions mediated and/or potentiated by these compounds. B. caapi is a constituent of Ayahuasca, a traditional hallucinogenic beverage, ingested in rituals by the Amazonian tribes, in Brazil. Meanwhile, P. harmala is a medicinal plant native to North Africa, Mediterranean Sea and Middle East, and introduced and naturalized in parts of the Southwest USA, justifying the interest of these countries (Spain, USA and Brazil) to explore the pharmacological potential of their compounds [20]. Concerning the annual evolution of the publications, a significant number of articles has been published in the last ten years (10 reports, 38.5\%), indicating that depression treatment using $\beta$-carboline alkaloids is still a recent issue and continues to attract researchers' attention worldwide (Fig. 4).

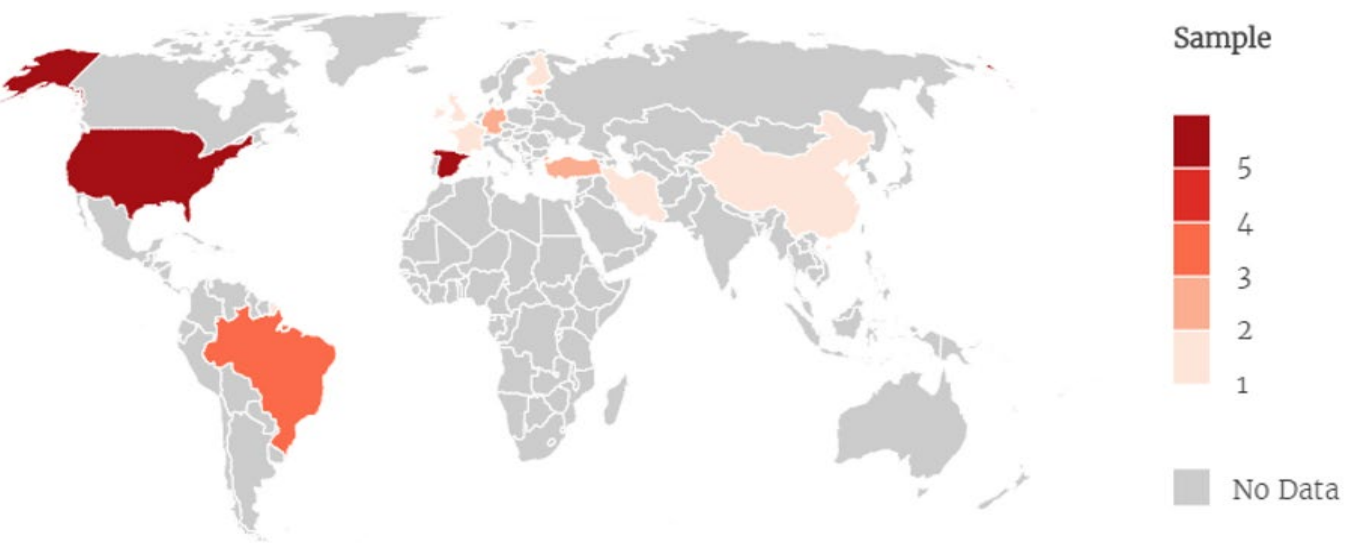

Fig. 3. Distribution of the included articles (sample) by country. Spain (07 reports), USA (06 reports) and Brazil (03 reports) were the main countries where studies involving $\beta$ carbolines as antidepressant agents have been performed. Studies performed in Turkey (02), France (01), Iran (01), UK (01), China (01), Germany (02), Estonia (02), Finland (01), Serbia (01), Croatia (01) and Ireland (01) were also found in this systematic review. 


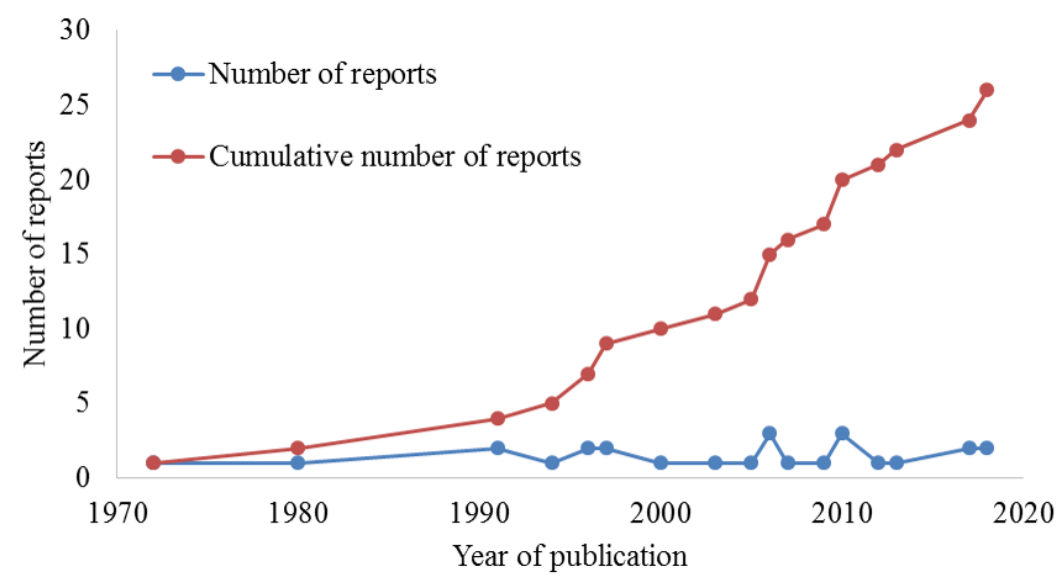

Fig. 4. Distribution of included articles by year of publication.

This systematic review consisted of 10 in vitro and 16 in vivo studies. Word clouds elaborated with both types of studies are presented in Fig. 5. Word clouds are images composed of main terms related to a particular subject, in which the size of each word indicates its frequency or relevance. Consequently, they provide an overview of a set of reports before even doing a detailed analysis. For the in vitro studies, the words $M A O, M A O-A$, inhibition and inhibitors were most frequently quoted, indicating that these studies were probably intended to evaluate the inhibitory effect of $\beta$-carbolines on the enzyme monoamine oxidase (MAO), specially the A-isoform (MAO-A). Similarly, the words harmane (syn. harman), harmine, rats, antidepressant, pinoline, forced swim test, immobility, MAO-A, 5-HT and levels are among the most cited in in vivo studies, providing some clues about of the main alkaloids tested in animal models, behavioral protocols, parameters evaluated and molecular targets investigated. However, as word clouds remain a superficial analysis, we present a more detailed discussion of included studies below. 


\section{In vitro studies}

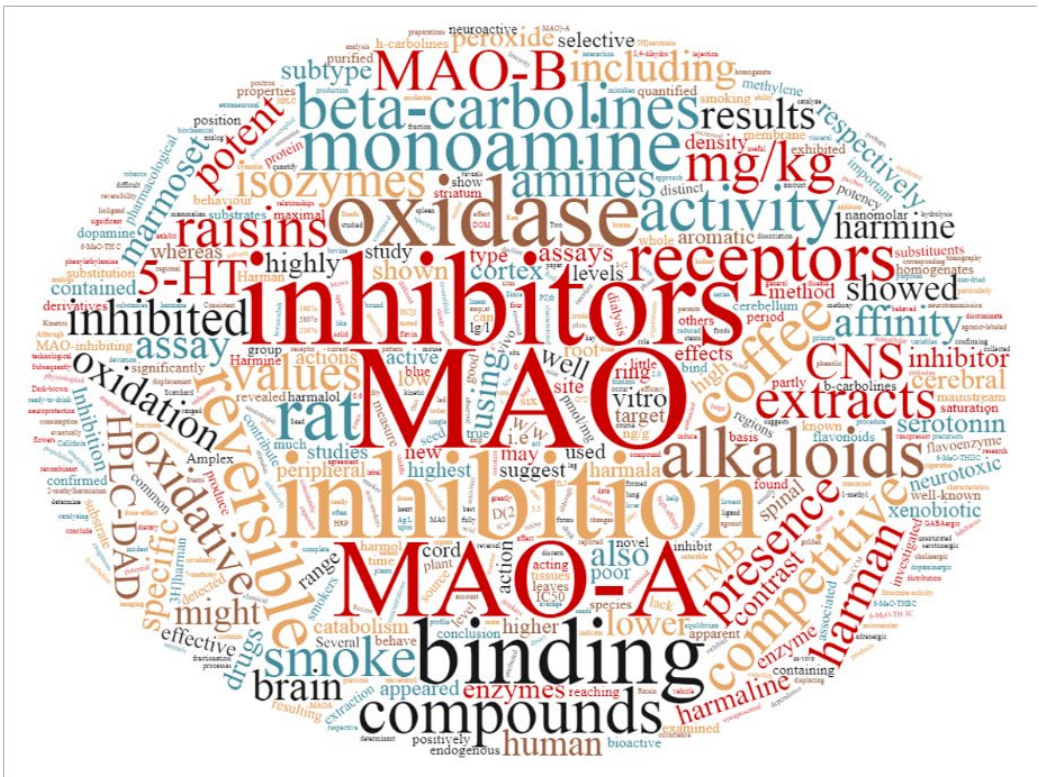

\section{In vivo studies}

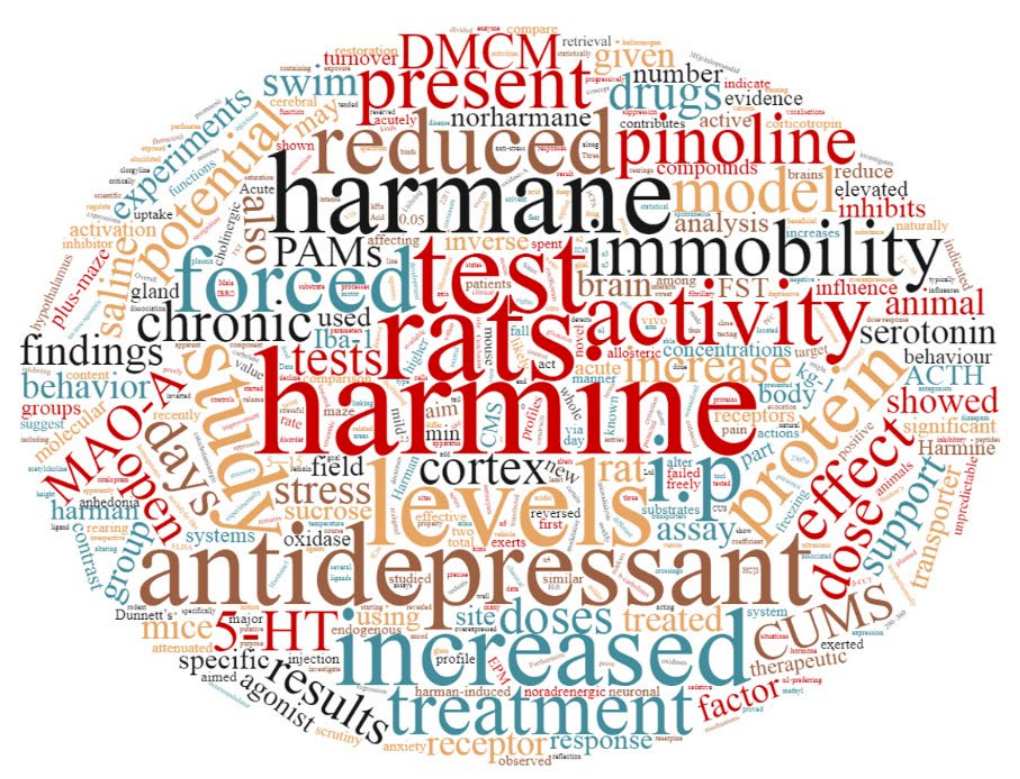

Fig. 5. Word clouds elaborated from the abstracts of in vitro and in vivo studies. The size of each word is proportional to the number of times it was quoted throughout the text.

\subsection{In vitro studies}

A total of 35 different $\beta$-carbolines has been evaluated in vitro (Table 1, Fig. 6). In general, the experimental protocols consisted of enzymatic inhibition assays using both $\mathrm{MAO}-\mathrm{A}$ and MAO-B isoforms, and binding assays using different cell lines expressing 
serotonin $\left(5-\mathrm{HT}_{1 \mathrm{~A}}, 5-\mathrm{HT}_{2 \mathrm{~A}}\right.$ and $\left.5-\mathrm{HT}_{2} \mathrm{C}\right)$, dopamine (D2) and/or benzodiazepine (BZ) receptors. In the first case, the results were mostly expressed in $\mathrm{IC}_{50}$, while in the second case the inhibition constant $\left(\mathrm{K}_{i}\right)$ was calculated for the determination of the affinity of the compounds tested with the different receptors investigated.

Although some reports have shown that carbolines are able to inhibit MAO-B, most of the evidences points to a selective inhibition of MAO-A, in some cases considered as a competitive and reversible inhibition. MAOs are a family of enzymes that catalyze the oxidation of monoamines, degrading them in the synaptic cleft and consequently reducing the activation of their respective receptors. There are two know MAO isoforms: MAO-A and MAO-B. MAO-A is characterized by preferentially binding to serotonin and noradrenaline, while MAO-B interacts more readily with phenethylamine and benzylamine [33-35].

In addition to acting as MAO inhibitors (MAOIs), $\beta$-carbolines are also capable of binding to serotonergic $\left(5-\mathrm{HT}_{1 \mathrm{~A}}, 5-\mathrm{HT}_{2 \mathrm{~A}}, 5-\mathrm{HT}_{2} \mathrm{C}\right)$ and benzodiazepine receptors [28]. The affinity for each receptor varies according to the $\beta$-carboline group $(\mathrm{BC}, \mathrm{DHBC}$ or THBC) and its substitution pattern (Table 1). However, these compounds had no significant affinity for dopaminergic receptors, suggesting that their central action may be restricted to 5-HT and GABA neurotransmission systems. Molecular mechanisms and structure-activity relationship aspects will be discussed in depth throughout this review. 
Fully aromatic derivatives<smiles>[R]c1ccc2c3cc[n+]([R])c([R3])c3n([R2])c2c1</smiles>

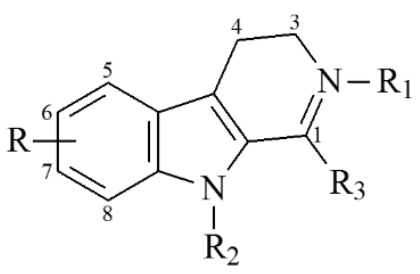

Tetrahydro derivatives

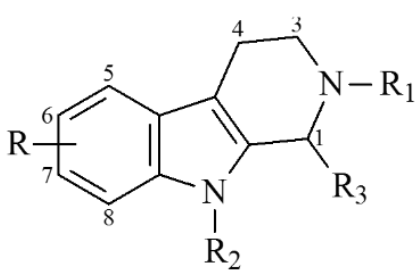

Others derivatives<smiles>[R]c1cc2c(cn1)[nH]c1ccccc12</smiles>

\begin{tabular}{lllll}
\hline $\mathbf{R}:$ & $\mathbf{R}_{\mathbf{1}}:$ & $\mathbf{R}_{\mathbf{2}}:$ & $\mathbf{R}_{\mathbf{3}}:$ & Compound: \\
\hline$-\mathrm{H}$ & - & $-\mathrm{H}$ & $-\mathrm{CH}_{3}$ & Harman \\
$5-\mathrm{OCH}_{3}$ & - & $-\mathrm{H}$ & $-\mathrm{CH}_{3}$ & 5-methoxyharman \\
$8-\mathrm{OCH}_{3}$ & - & $-\mathrm{H}$ & $-\mathrm{CH}_{3}$ & 8-methoxyharman \\
$-\mathrm{H}$ & $-\mathrm{CH}_{3}$ & $-\mathrm{H}$ & $-\mathrm{CH}_{3}$ & 2-methylharman \\
$-\mathrm{H}$ & $-\mathrm{CH}_{3}$ & $-\mathrm{CH}_{3}$ & $-\mathrm{CH}_{3}$ & 2,9-dimethylharman \\
$7-\mathrm{OCH}_{3}$ & - & $-\mathrm{H}$ & $-\mathrm{CH}_{3}$ & Harmine \\
$7-\mathrm{OCH}_{3}$ & $-\mathrm{CH}_{3}$ & $-\mathrm{H}$ & $-\mathrm{CH}_{3}$ & 2-methylharmine \\
$7-\mathrm{OCH}_{3}$ & $-\mathrm{CH}_{3}$ & $-\mathrm{CH}_{3}$ & $-\mathrm{CH}_{3}$ & 2,9-dimethylharmine \\
$-\mathrm{H}$ & - & $-\mathrm{H}$ & $-\mathrm{H}$ & Norharman \\
$-\mathrm{H}$ & $-\mathrm{CH}_{3}$ & $-\mathrm{H}$ & $-\mathrm{H}$ & 2-methylhorharman \\
$-\mathrm{H}$ & $-\mathrm{CH}_{3}$ & $-\mathrm{CH}$ & $-\mathrm{H}$ & 2,9-dimethylnorharman \\
$7-\mathrm{OH}$ & - & $-\mathrm{H}$ & $-\mathrm{CH}_{3}$ & Harmol \\
\hline
\end{tabular}

\begin{tabular}{lllll}
\hline $\mathbf{R}:$ & $\mathbf{R}_{\mathbf{1}}:$ & $\mathbf{R}_{2}:$ & $\mathbf{R}_{\mathbf{3}}:$ & Compound: \\
\hline$-\mathrm{H}$ & - & $-\mathrm{H}$ & $-\mathrm{CH}_{3}$ & Harmalan \\
6-OCH & $-\mathrm{CH}_{3}$ & $-\mathrm{H}$ & $-\mathrm{CH}_{3}$ & 2-methyl-6-methoxyharmalan \\
$5-\mathrm{CH}_{3}$ & - & $-\mathrm{H}$ & $-\mathrm{CH}_{3}$ & 5-methylharmalan \\
$5-\mathrm{OCH}_{3}$ & - & $-\mathrm{H}$ & $-\mathrm{CH}_{3}$ & 5-methoxyharmalan \\
$6-\mathrm{OCH}_{3}$ & - & $-\mathrm{H}$ & $-\mathrm{CH}_{3}$ & 6-methoxyharmalan \\
$8-\mathrm{OCH}_{3}$ & - & $-\mathrm{H}$ & $-\mathrm{CH}_{3}$ & 8-methoxyharmalan \\
$7-\mathrm{OCH}_{3}$ & - & $-\mathrm{H}$ & $-\mathrm{CH}_{3}$ & Harmaline \\
$7-\mathrm{OCH}_{3}$ & $-\mathrm{CH}_{3}$ & $-\mathrm{H}$ & $-\mathrm{CH}_{3}$ & 2-methylharmaline \\
$7-\mathrm{OCH}$ & - & $-\mathrm{H}$ & - & Desmethylharmaline \\
$7-\mathrm{OH}$ & - & $-\mathrm{H}$ & $-\mathrm{CH}_{3}$ & Harmalol \\
\hline
\end{tabular}

\begin{tabular}{lllll}
\hline $\mathbf{R}:$ & $\mathbf{R}_{\mathbf{1}}:$ & $\mathbf{R}_{2}:$ & $\mathbf{R}_{\mathbf{3}}:$ & Compound: \\
\hline$-\mathrm{H}$ & - & $-\mathrm{H}$ & $-\mathrm{CH}_{3}$ & Tetrahydroharman \\
$5-\mathrm{OCH}_{3}$ & - & $-\mathrm{H}$ & $-\mathrm{CH}_{3}$ & 5-methoxy-tetrahydroharman \\
$6-\mathrm{OCH}_{3}$ & - & $-\mathrm{H}$ & $-\mathrm{CH}_{3}$ & 6-methoxy-tetrahydroharman \\
$8-\mathrm{OCH}_{3}$ & - & $-\mathrm{H}$ & $-\mathrm{CH}_{3}$ & 8-methoxy-tetrahydroharman \\
$7-\mathrm{OCH}_{3}$ & - & $-\mathrm{H}$ & $-\mathrm{CH}_{3}$ & Tetrahydroharmine \\
$-\mathrm{H}$ & - & $-\mathrm{H}$ & $-\mathrm{H}$ & Tetrahydronorharman \\
$6-\mathrm{OCH}_{3}$ & - & $-\mathrm{H}$ & $-\mathrm{H}$ & 6-methoxy-tetrahydronorharman (pinoline) \\
$7-\mathrm{OCH}_{3}$ & - & $-\mathrm{H}$ & $-\mathrm{H}$ & 7-methoxy-tetrahydronorharman \\
7- $-\mathrm{OCH}_{3}$ & $-\mathrm{CH}_{3}$ & $-\mathrm{H}$ & $-\mathrm{H}$ & 2-methyl-7-methoxy-tetrahydronorharman \\
& & & &
\end{tabular}

\begin{tabular}{ll}
\hline R: & Compound: \\
\hline$-\mathrm{COOCH}_{3}$ & $\beta-\mathrm{CCM}$ \\
$-\mathrm{CONHCH}_{3}$ & $\beta-\mathrm{CCM}$ amide (FG 7142) \\
$-\mathrm{COOC}_{(}\left(\mathrm{CH}_{3}\right)_{3}$ & $\beta-\mathrm{CCT}$ \\
\hline
\end{tabular}<smiles>CCc1c(C(=O)OC)ncc2[nH]c3cc(OC)c(OC)cc3c12</smiles>

DMCM

Fig. 6. Chemical structures of all $\beta$-carboline alkaloids investigated as antidepressant agents in in vitro and/or in vivo reports. 
Table 1. Main characteristics of in vitro studies included in this systematic review. Chemical structures are shown in Fig. 6.

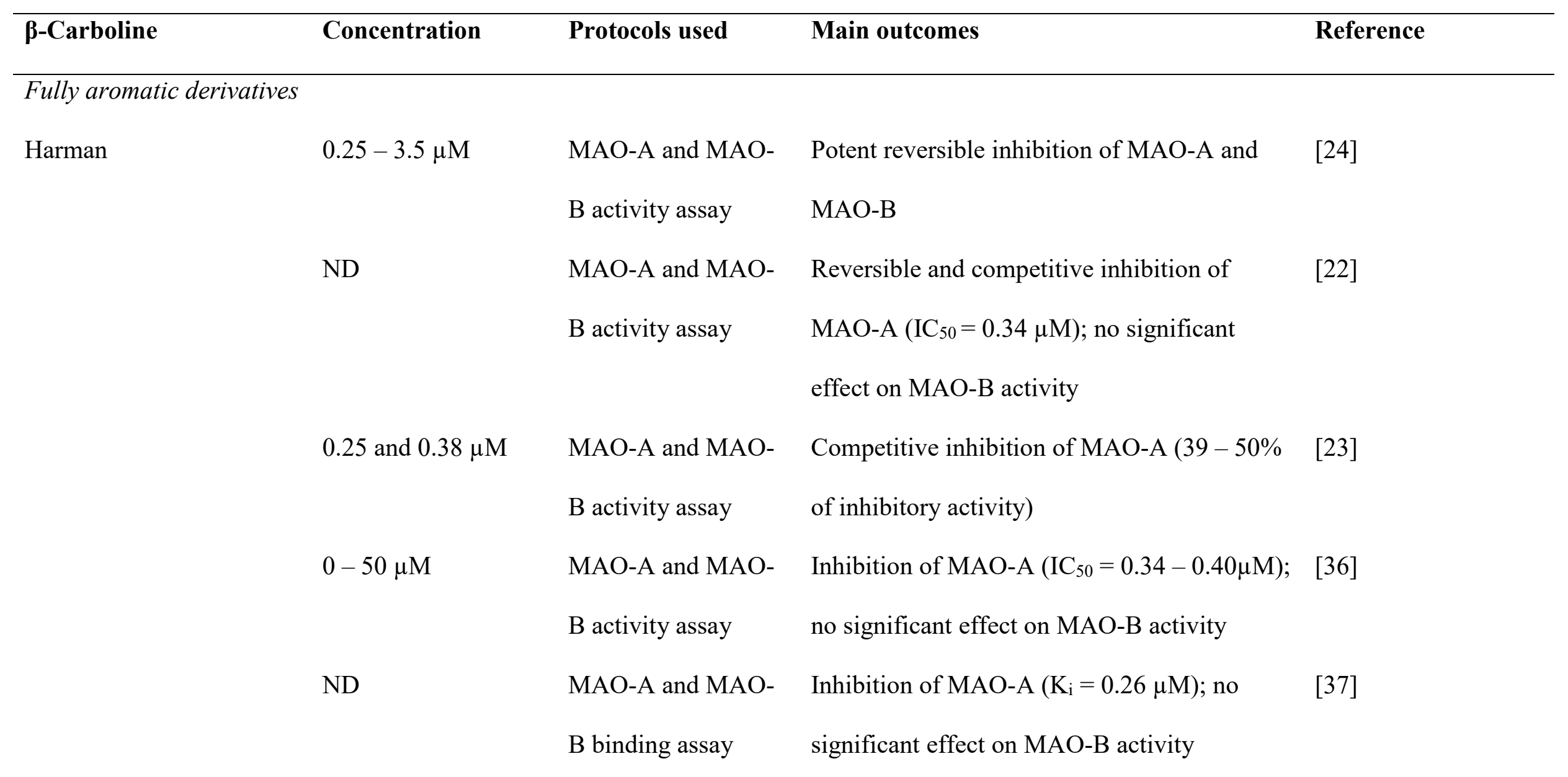


$0.1-50 \mathrm{nM}$

ND

$10^{-5}-10^{-9} \mathrm{M}$

ND

2-methylharman

2,9-dimethylharman
MAO-A and MAO- Inhibition of MAO-A $\left(\mathrm{K}_{\mathrm{i}}=220 \mathrm{nM}\right)$ and

$\mathrm{B}$ binding assay

MAO-B $\left(\mathrm{K}_{\mathrm{i}}=57,000 \mathrm{nM}\right)$

MAO-A and MAO- Selective inhibition of MAO-A

[39]

B binding assay

MAO-A and MAO- Tight binding inhibition of MAO-A $\left(\mathrm{IC}_{50}=\right.$

B activity and $\quad 30 \mathrm{nM})$; no significant effect on MAO-B

binding assay activity

5-HT, DA and BZ Moderate affinity to 5- $\mathrm{HT}_{2 \mathrm{~A}}$ receptors $\left(\mathrm{K}_{\mathrm{i}}=\right.$

receptors binging $268 \mathrm{nM}$ ); weak affinity to $5-\mathrm{HT}_{2 \mathrm{C}}$ receptors

assay

$\left(\mathrm{K}_{\mathrm{i}}=2,490 \mathrm{nM}\right)$

MAO-A and MAO- $\quad$ Inhibition of MAO-A $\left(\mathrm{K}_{\mathrm{i}}=0.68 \mu \mathrm{M}\right)$; no

B binding assay

significant effect on MAO-B activity

MAO-A and MAO- $\quad$ Inhibition of MAO-A $\left(\mathrm{K}_{\mathrm{i}}=0.16 \mu \mathrm{M}\right)$; no

significant effect on MAO-B activity 


\begin{tabular}{|c|c|c|c|c|}
\hline 5-methoxyharman & ND & $\begin{array}{l}5-\mathrm{HT}, \mathrm{DA} \text { and } \mathrm{BZ} \\
\text { receptors binging }\end{array}$ & $\begin{array}{l}\text { Weak affinity to } 5-\mathrm{HT}_{2 \mathrm{~A}} \text { receptors }\left(\mathrm{K}_{\mathrm{i}}=1,340\right. \\
\mathrm{nM}) ; \text { moderate affinity to } 5-\mathrm{HT}_{2 \mathrm{C}} \text { receptors }\end{array}$ & {$[28]$} \\
\hline & & assay & $\left(\mathrm{K}_{\mathrm{i}}=417 \mathrm{nM}\right)$ & \\
\hline 6-methoxyharman & $10^{-5}-10^{-9} \mathrm{M}$ & $\begin{array}{l}\text { MAO-A and MAO- } \\
\text { B activity and } \\
\text { binding assay }\end{array}$ & $\begin{array}{l}\text { Competitive inhibition of MAO-A }\left(\mathrm{IC}_{50}=\right. \\
500 \mathrm{nM}) \text {; no significant effect on MAO-B } \\
\text { activity }\end{array}$ & {$[40]$} \\
\hline & ND & $\begin{array}{l}\text { 5-HT, DA and BZ } \\
\text { receptors binging }\end{array}$ & $\begin{array}{l}\text { Weak affinity to } 5-\mathrm{HT}_{2 \mathrm{C}}\left(\mathrm{K}_{\mathrm{i}}=3,700 \mathrm{nM}\right) \\
\text { receptors }\end{array}$ & [28] \\
\hline & & assay & & \\
\hline 8-methoxyharman & ND & $\begin{array}{l}\text { 5-HT, DA and BZ } \\
\text { receptors binging } \\
\text { assay }\end{array}$ & $\begin{array}{l}\text { Weak affinity to } 5-\mathrm{HT}_{2 \mathrm{C}}\left(\mathrm{K}_{\mathrm{i}}=2,530 \mathrm{nM}\right) \\
\text { receptors }\end{array}$ & {$[28]$} \\
\hline Harmine & ND & $\begin{array}{l}\text { MAO-A and MAO- } \\
\text { B activity assay }\end{array}$ & $\begin{array}{l}\text { Inhibition of MAO-A }\left(\mathrm{IC}_{50}=8.7 \mathrm{nM}\right) \text {; no } \\
\text { significant effect on MAO-B activity }\end{array}$ & {$[20]$} \\
\hline
\end{tabular}




\begin{tabular}{|c|c|c|c|}
\hline & $0-50 \mu \mathrm{M}$ & MAO-A and MAO- & Inhibition of MAO-A $\left(\mathrm{IC}_{50}=0.023-0.025\right.$ \\
\hline & & $B$ activity assay & $\mu \mathrm{M})$; no significant effect on MAO-B activity \\
\hline & ND & MAO-A and MAO- & Inhibition of MAO-A $\left(\mathrm{K}_{\mathrm{i}}=0.005 \mu \mathrm{M}\right)$; no \\
\hline & & $\mathrm{B}$ binding assay & significant effect on MAO-B activity \\
\hline & $10^{-5}-10^{-9} \mathrm{M}$ & MAO-A and MAO- & Tight binding inhibition of MAO-A $\left(\mathrm{IC}_{50}=\right.$ \\
\hline & & $B$ activity and & $1.0 \mathrm{nM}$ ); no significant effect on MAO-B \\
\hline & & binding assay & activity \\
\hline & ND & 5-HT, DA and BZ & Moderate affinity to $5-\mathrm{HT}_{2 \mathrm{~A}}$ receptors $\left(\mathrm{K}_{\mathrm{i}}=\right.$ \\
\hline & & receptors binging & $397 \mathrm{nM})$ Weak affinity to $5-\mathrm{HT}_{2 \mathrm{C}}$ receptors \\
\hline & & assay & $\left(\mathrm{K}_{\mathrm{i}}=5,340 \mathrm{nM}\right)$ \\
\hline 2-methylharmine & ND & MAO-A and MAO- & Inhibition of MAO-A $\left(\mathrm{K}_{\mathrm{i}}=0.069 \mu \mathrm{M}\right)$; no \\
\hline & & $\mathrm{B}$ binding assay & significant effect on MAO-B activity \\
\hline 2,9-dimethylharmine & ND & MAO-A and MAO- & Inhibition of MAO-A $\left(\mathrm{K}_{\mathrm{i}}=0.015 \mu \mathrm{M}\right)$; no \\
\hline & & $\mathrm{B}$ biding assay & significant effect on MAO-B activity \\
\hline
\end{tabular}




\begin{tabular}{|c|c|c|c|c|}
\hline \multirow[t]{11}{*}{ Norharman } & \multirow[t]{2}{*}{$3.0-40 \mu \mathrm{M}$} & MAO-A and MAO- & Potent reversible inhibition of MAO-A and & {$[24]$} \\
\hline & & B activity assay & MAO-B & \\
\hline & \multirow[t]{3}{*}{ ND } & MAO-A and MAO- & Reversible and competitive inhibition of & {$[22]$} \\
\hline & & $B$ activity assay & MAO-A $\left(\mathrm{IC}_{50}=6.4 \mu \mathrm{M}\right)$ and MAO-B $\left(\mathrm{IC}_{50}=\right.$ & \\
\hline & & & $4.7 \mu \mathrm{M})$ & \\
\hline & \multirow[t]{2}{*}{2.0 and $4.0 \mu \mathrm{M}$} & MAO-A and MAO- & Competitive inhibition of MAO-B (20 - 36\% & {$[23]$} \\
\hline & & B activity assay & of inhibitory activity) & \\
\hline & \multirow[t]{2}{*}{$0-50 \mu \mathrm{M}$} & MAO-A and MAO- & Inhibition of MAO-A $\left(\mathrm{IC}_{50}=8.0-8.10 \mu \mathrm{M}\right)$ & {$[36]$} \\
\hline & & B activity assay & and MAO-B $(6.0-6.9 \mu \mathrm{M})$ & \\
\hline & \multirow[t]{2}{*}{ ND } & MAO-A and MAO- & Inhibition of MAO-A $\left(\mathrm{K}_{\mathrm{i}}=3.34 \mu \mathrm{M}\right)$; no & {$[37]$} \\
\hline & & $\mathrm{B}$ binding assay & significant effect on MAO-B activity & \\
\hline \multirow[t]{2}{*}{ 2-methylnorharman } & \multirow[t]{2}{*}{ ND } & MAO-A and MAO- & Inhibition of MAO-A $\left(\mathrm{K}_{\mathrm{i}}=1.43 \mu \mathrm{M}\right)$; no & [37] \\
\hline & & $\mathrm{B}$ binding assay & significant effect on MAO-B activity & \\
\hline \multirow[t]{2}{*}{ 2,9-dimethylnorharman } & \multirow[t]{2}{*}{ ND } & MAO-A and MAO- & Inhibition of MAO-A $\left(\mathrm{K}_{\mathrm{i}}=0.41 \mu \mathrm{M}\right)$; no & [37] \\
\hline & & $\mathrm{B}$ binding assay & significant effect on MAO-B activity & \\
\hline
\end{tabular}




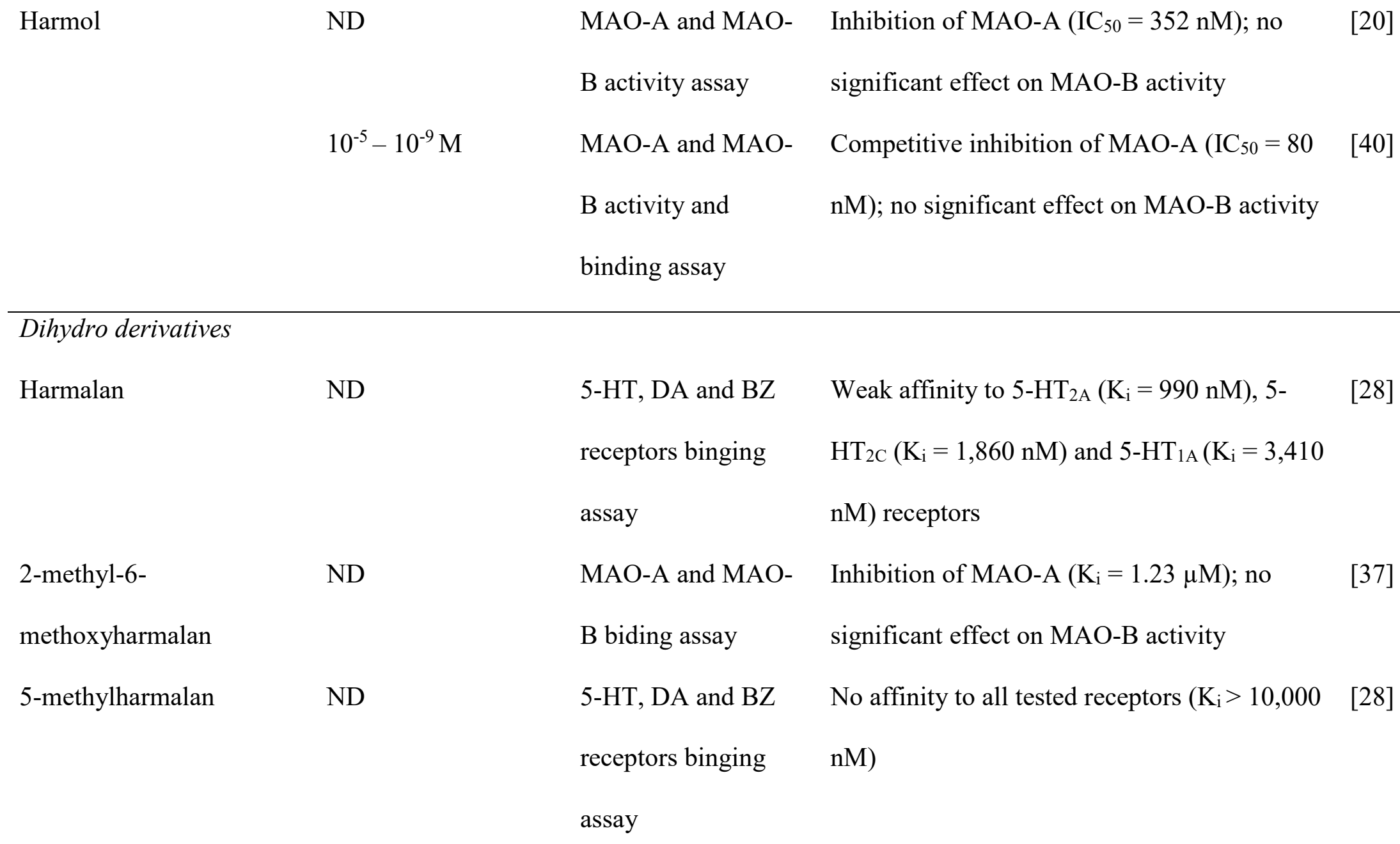




\begin{tabular}{|c|c|c|c|c|}
\hline \multirow[t]{3}{*}{ 5-methoxyharmalan } & ND & 5-HT, DA and BZ & High affinity to $5-\mathrm{HT}_{2 \mathrm{~A}}\left(\mathrm{~K}_{\mathrm{i}}=86 \mathrm{nM}\right)$ and 5- & {$[28]$} \\
\hline & & receptors binging & $\mathrm{HT}_{2 \mathrm{C}}\left(\mathrm{K}_{\mathrm{i}}=69 \mathrm{nM}\right)$ receptors; weak affinity to & \\
\hline & & assay & $5-\mathrm{HT}_{1 \mathrm{~A}}\left(\mathrm{~K}_{\mathrm{i}}=6,190 \mathrm{nM}\right)$ receptors & \\
\hline \multirow[t]{8}{*}{ 6-methoxyharmalan } & ND & MAO-A and MAO- & Inhibition of MAO-A $\left(\mathrm{K}_{\mathrm{i}}=0.39 \mu \mathrm{M}\right)$; no & [37] \\
\hline & & $\mathrm{B}$ biding assay & significant effect on MAO-B activity & \\
\hline & $10^{-5}-10^{-9} \mathrm{M}$ & MAO-A and MAO- & Competitive inhibition of MAO-A $\left(\mathrm{IC}_{50}=\right.$ & {$[40]$} \\
\hline & & $B$ activity and & $2000 \mathrm{nM}$ ); no significant effect on MAO-B & \\
\hline & & binding assay & activity & \\
\hline & ND & 5-HT, DA and BZ & Weak affinity to $5-\mathrm{HT}_{2 \mathrm{~A}}\left(\mathrm{~K}_{\mathrm{i}}=4,220 \mathrm{nM}\right)$ and & [28] \\
\hline & & receptors binging & $5-\mathrm{HT}_{2 \mathrm{C}}\left(\mathrm{K}_{\mathrm{i}}=924 \mathrm{nM}\right)$ receptors & \\
\hline & & assay & & \\
\hline \multirow[t]{3}{*}{ 8-methoxyharmalan } & ND & 5-HT, DA and BZ & Weak affinity to $5-\mathrm{HT}_{2 \mathrm{~A}}\left(\mathrm{~K}_{\mathrm{i}}=1,560 \mathrm{nM}\right), 5-$ & {$[28]$} \\
\hline & & receptors binging & $\mathrm{HT}_{2 \mathrm{C}}\left(\mathrm{K}_{\mathrm{i}}=2,130 \mathrm{nM}\right)$ and $5-\mathrm{HT}_{1 \mathrm{~A}}\left(\mathrm{~K}_{\mathrm{i}}=3,000\right.$ & \\
\hline & & assay & $\mathrm{nM}$ ) receptors & \\
\hline
\end{tabular}




\begin{tabular}{|c|c|c|c|c|}
\hline Harmaline & ND & MAO-A and MAO- & Inhibition of MAO-A $\left(\mathrm{IC}_{50}=11.8 \mathrm{nM}\right)$; no & {$[20]$} \\
\hline & & B activity assay & effect on MAO-B activity & \\
\hline & $0-50 \mu \mathrm{M}$ & MAO-A and MAO- & Inhibition of MAO-A $\left(\mathrm{IC}_{50}=0.025 \mu \mathrm{M}\right)$; no & [36] \\
\hline & & B activity assay & significant effect on MAO-B activity & \\
\hline & ND & MAO-A and MAO- & Inhibition of MAO-A $\left(\mathrm{K}_{\mathrm{i}}=0.048 \mu \mathrm{M}\right)$; no & [37] \\
\hline & & B biding assay & significant effect on MAO-B activity & \\
\hline & $10^{-5}-10^{-9} \mathrm{M}$ & MAO-A and MAO- & Tight binding inhibition of MAO-A $\left(\mathrm{IC}_{50}=\right.$ & {$[40]$} \\
\hline & & $B$ activity and & $7.0 \mathrm{nM}$ ); no significant effect on MAO-B & \\
\hline & & binding assay & activity & \\
\hline & ND & 5-HT, DA and BZ & Weak affinity to $5-\mathrm{HT}_{2 \mathrm{~A}}\left(\mathrm{~K}_{\mathrm{i}}=5,010 \mathrm{nM}\right)$ and & {$[28]$} \\
\hline & & receptors binging & $5-\mathrm{HT}_{2 \mathrm{C}}\left(\mathrm{K}_{\mathrm{i}}=9,430 \mathrm{nM}\right)$ receptors & \\
\hline & & assay & & \\
\hline 2-methylharmaline & ND & MAO-A and MAO- & Inhibition of MAO-A $\left(\mathrm{K}_{\mathrm{i}}=0.14 \mu \mathrm{M}\right)$; no & {$[37]$} \\
\hline & & B biding assay & significant effect on MAO-B activity & \\
\hline
\end{tabular}




\begin{tabular}{|c|c|c|c|c|}
\hline Desmethylharmaline & ND & $\begin{array}{l}\text { 5-HT, DA and BZ } \\
\text { receptors binging }\end{array}$ & $\begin{array}{l}\text { No affinity to all tested receptors }\left(\mathrm{K}_{\mathrm{i}}>10,000\right. \\
\mathrm{nM})\end{array}$ & [28] \\
\hline & & assay & & \\
\hline \multirow[t]{3}{*}{ Harmalol } & ND & $\begin{array}{l}\text { MAO-A and MAO- } \\
\text { B activity assay }\end{array}$ & $\begin{array}{l}\text { Inhibition of MAO-A }\left(\mathrm{IC}_{50}=480 \mathrm{nM}\right) \text {; no } \\
\text { significant effect on MAO-B activity }\end{array}$ & {$[20]$} \\
\hline & $10^{-5}-10^{-9} \mathrm{M}$ & $\begin{array}{l}\text { MAO-A and MAO- } \\
\text { B activity and } \\
\text { binding assay }\end{array}$ & $\begin{array}{l}\text { Competitive inhibition of MAO-A }\left(\mathrm{IC}_{50}=\right. \\
100 \mathrm{nM}) \text {; no significant effect on MAO-B } \\
\text { activity }\end{array}$ & {$[40]$} \\
\hline & ND & $\begin{array}{l}5-\mathrm{HT}, \mathrm{DA} \text { and } \mathrm{BZ} \\
\text { receptors binging } \\
\text { assay }\end{array}$ & $\begin{array}{l}\text { No affinity to all tested receptors }\left(\mathrm{K}_{\mathrm{i}}>10,000\right. \\
\mathrm{nM})\end{array}$ & [28] \\
\hline \multicolumn{5}{|l|}{ Tetrahydro derivatives } \\
\hline Tetrahydroharman & ND & $\begin{array}{l}\text { 5-HT, DA and BZ } \\
\text { receptors binging } \\
\text { assay }\end{array}$ & $\begin{array}{l}\text { Weak affinity to } 5-\mathrm{HT}_{2 \mathrm{~A}} \text { receptors }\left(\mathrm{K}_{\mathrm{i}}=1,430\right. \\
\mathrm{nM})\end{array}$ & {$[28]$} \\
\hline
\end{tabular}




\begin{tabular}{|c|c|c|c|c|}
\hline 5-methoxy- & ND & 5-HT, DA and BZ & Moderate affinity to $5-\mathrm{HT}_{2 \mathrm{~A}}$ receptors $\left(\mathrm{K}_{\mathrm{i}}=\right.$ & [28] \\
\hline \multirow[t]{2}{*}{ tetrahydroharman } & & receptors binging & $237 \mathrm{nM})$; weak affinity to $5-\mathrm{HT}_{2 \mathrm{C}}\left(\mathrm{K}_{\mathrm{i}}=1,060\right.$ & \\
\hline & & assay & $\mathrm{nM})$ and $5-\mathrm{HT}_{1 \mathrm{~A}}\left(\mathrm{~K}_{\mathrm{i}}=2,000 \mathrm{nM}\right)$ receptors & \\
\hline \multirow{3}{*}{$\begin{array}{l}\text { 6-methoxy- } \\
\text { tetrahydroharman }\end{array}$} & ND & 5-HT, DA and BZ & Weak affinity to $5-\mathrm{HT}_{2 \mathrm{~A}}$ receptors $\left(\mathrm{K}_{\mathrm{i}}=4,360\right.$ & {$[28]$} \\
\hline & & receptors binging & $\mathrm{nM})$ & \\
\hline & & assay & & \\
\hline \multirow{3}{*}{$\begin{array}{l}\text { 8-methoxy- } \\
\text { tetrahydroharman }\end{array}$} & ND & 5-HT, DA and BZ & Moderate affinity to $5-\mathrm{HT}_{2 \mathrm{~A}}\left(\mathrm{~K}_{\mathrm{i}}=770 \mathrm{nM}\right)$, & {$[28]$} \\
\hline & & receptors binging & $5-\mathrm{HT}_{2 \mathrm{C}}\left(\mathrm{K}_{\mathrm{i}}=710 \mathrm{nM}\right)$ and $5-\mathrm{HT}_{1 \mathrm{~A}}\left(\mathrm{~K}_{\mathrm{i}}=450\right.$ & \\
\hline & & assay & $\mathrm{nM}$ ) receptors & \\
\hline \multirow[t]{3}{*}{ Tetrahydroharmine } & ND & 5-HT, DA and BZ & No affinity to all tested receptors $\left(\mathrm{K}_{\mathrm{i}}>10,000\right.$ & {$[28]$} \\
\hline & & receptors binging & $\mathrm{nM})$ & \\
\hline & & assay & & \\
\hline \multirow[t]{3}{*}{ Tetrahydronorharman } & $10^{-5}-10^{-9} \mathrm{M}$ & MAO-A and MAO- & Competitive inhibition of MAO-A $\left(\mathrm{IC}_{50}=\right.$ & {$[40]$} \\
\hline & & B activity and & $8000 \mathrm{nM}$ ); no significant effect on MAO-B & \\
\hline & & binding assay & activity & \\
\hline
\end{tabular}




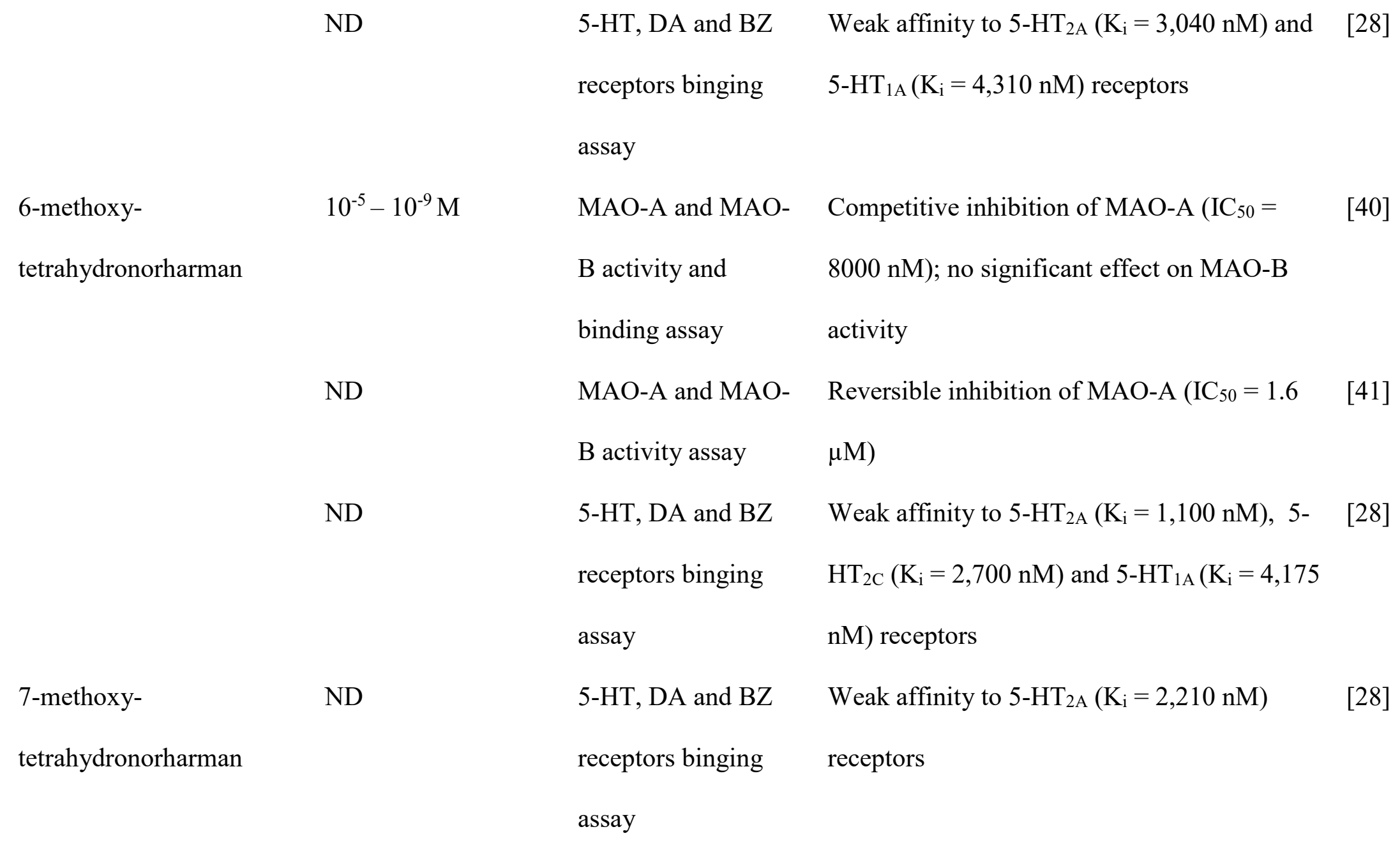




\begin{tabular}{|c|c|c|c|}
\hline 2-methyl-7-methoxy- & ND & 5-HT, DA and BZ & Weak affinity to $5-\mathrm{HT}_{2 \mathrm{~A}}\left(\mathrm{~K}_{\mathrm{i}}=2,040 \mathrm{nM}\right)$ and \\
\hline tetrahydronorharman & & receptors binging & $5-\mathrm{HT}_{2 \mathrm{C}}\left(\mathrm{K}_{\mathrm{i}}=3,360 \mathrm{nM}\right)$ receptors \\
\hline
\end{tabular}

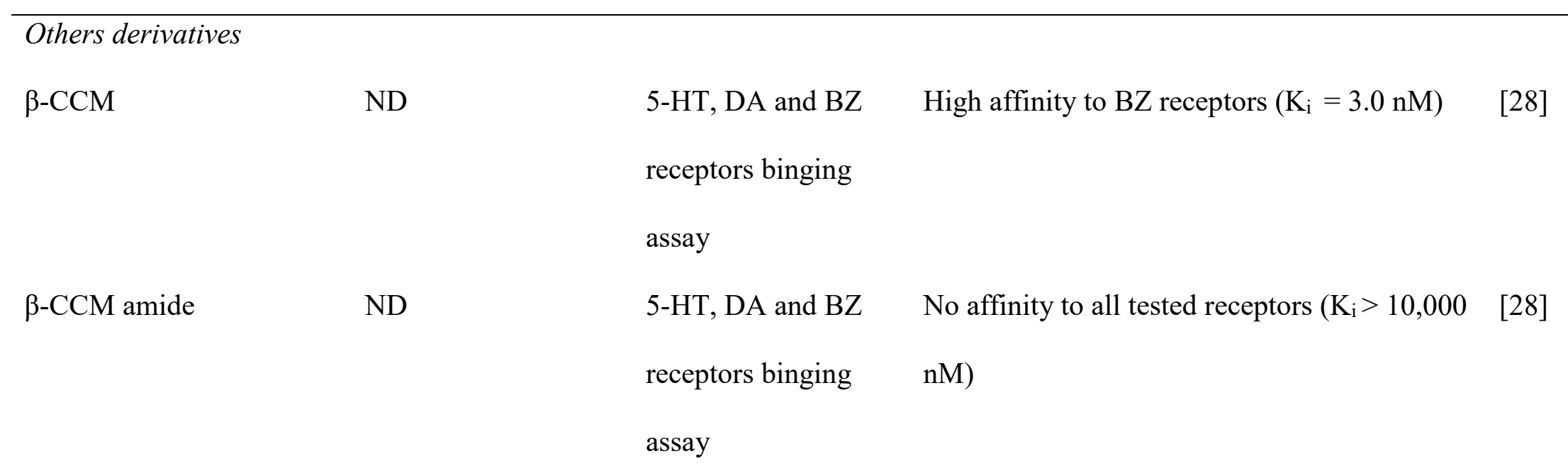

ND (not described).

5-HT (serotonin), BZ (benzodiazepine), DA (dopamine), IC 50 (half maximal inhibitory concentration), $\mathrm{K}_{\mathrm{i}}$ (inhibition constant), MAO-A (monoamine oxidase-A), MAO-B (monoamine oxidase-B), THBC (tetrahydro- $\beta$-carboline), $\beta$-CCM ( $\beta$-carboline-3-carboxylic acid methyl ester). 


\subsection{In vivo studies}

In vivo studies were designed to evaluate the effects of $\beta$-carbolines on behavioral parameters, monoamines levels (5-HT, NA and DA) or MAO activity (Table 2). In all reports, animals were treated intraperitoneally (i.p.), acutely or chronically, according to the experimental model used. Forced swimming (FST) and tail suspension (TST) tests were the most employed behavioral protocols, especially for evaluation of acute antidepressant activity. These are classic models for the screening of new antidepressant drugs and consist of subjecting animals to inescapable and conflicting situations. In the FST model, animals are placed in a water tank, while in the TST test they are suspended in a fixed apparatus by their tail. Thus, the antidepressant activity is measured by the immobility time, which reflects the degree of the animal's motivation to escape [42-44].

In some cases, FST and TST were performed after application of a chronic mild unpredictable stress protocol, which allows evaluating depression-like behaviors caused by similar etiologies that trigger human depression $[45,46]$. The exposure to repeated unavoidable stress induces a lower consumption of highly palatable food (e.g. sweet food, enriched with sucrose). This behavior is frequently associate to anhedonia (the loss of interest or pleasure) in animals, one of the main symptoms required for diagnosis of a major depressive episode in humans. Therefore, the sucrose preference test has also been reported in the included in vivo studies, commonly performed after chronic stress protocols to assess the efficacy of a long-term treatment ( 2 to 3 weeks, with different doses of $\beta$-carbolines) by restoring animals' motivation $[27,47]$.

However, animal models should be refined and efficiently conducted in order to obtain accurate and reliable data [48]. In this sense, we carefully investigated the methodological quality of all in vivo studies using a standard checklist (Fig. 7). Behavioral parameters, doses and routes of administration, frequency of treatment and main 
outcomes were adequately described in all articles. Although statistical analysis was properly reported in most investigations $(87.5 \%)$, no study reported sample size calculations. In addition, few studies reported randomization $(6.25 \%)$ and blinding (18.75\%) strategies. Randomization and blinding procedures are extremely recommended in preclinical trials. They reduce risk of bias and avoid unexpected results in clinical trials, especially when the experimental models involve evaluation of behavioral parameters [49-51]. For this reason, we consider that the in vivo studies included in this systematic review presented low to moderate methodological quality, which limits the interpretation of the results.

It is also important to note that in vivo studies have limitations, especially when they include experimental models based on behavioral parameters. Many factors may interfere with the quality of results, such as the subjective nature of behavioral response interpretation, standardization of experimental protocols, data analysis and validation of the animal model using standard drugs. For these reasons, clinical translation of preclinical experimental data is still a barrier to be overcome in the development of new antidepressants [52-54]. In this sense, it is recommended to perform different experimental protocols to confirm the pharmacological response in preclinical stages, using models that best reproduce clinical conditions and present minimal methodological bias. 
Table 2. In vivo studies involving the use of $\beta$-carboline alkaloids in experimental models to evaluate antidepressant effects. Chemical structures are shown in Fig. 6 .

\begin{tabular}{|c|c|c|c|c|c|c|c|}
\hline$\beta$-Carboline & Dose (via) & $\begin{array}{l}\text { Frequency } \\
\text { of } \\
\text { treatment }\end{array}$ & $\begin{array}{l}\text { Animal model } \\
\text { (n/group) }\end{array}$ & $\begin{array}{l}\text { Experimental } \\
\text { protocols }\end{array}$ & Results & $\begin{array}{l}\text { Mechanisms of } \\
\text { action }\end{array}$ & Reference \\
\hline $\begin{array}{l}\text { 6-methoxy- } \\
\text { tetrahydronorharman }\end{array}$ & $\begin{array}{l}2-200 \mathrm{mg} / \mathrm{kg} \\
\text { (i.p.) }\end{array}$ & Acute & $\begin{array}{l}\text { Female Yale- } \\
\text { Swiss mice and } \\
\text { male Sprague- } \\
\text { Dawley rats } \\
(\mathrm{n}=16)\end{array}$ & $\begin{array}{l}\text { 5-HT, 5-HIAA and } \\
\text { NE measurement }\end{array}$ & $\uparrow 5-\mathrm{HT}$ and NA & $\begin{array}{l}\mathrm{MAO}-\mathrm{A} / \mathrm{B} \\
\text { inhibition }\end{array}$ & {$[55]$} \\
\hline & $\begin{array}{l}25-150 \\
\text { mg/kg (i.p.) }\end{array}$ & Acute & $\begin{array}{l}\text { Female CF-1 } \\
\text { mice (ND) }\end{array}$ & $\begin{array}{l}\text { Measurement of } \\
\text { MAO-A and MAO-B } \\
\text { activity }\end{array}$ & $\begin{array}{l}\text { Preferential MAO-A } \\
\text { inhibition }\end{array}$ & $\begin{array}{l}\text { MAO-A } \\
\text { inhibition }\end{array}$ & [41] \\
\hline
\end{tabular}




\begin{tabular}{|c|c|c|c|c|c|c|}
\hline \multirow[t]{3}{*}{ DMCM } & $0.05,0.1,0.5$ & Acute & Male Wistar & FST, AAT and & $\downarrow$ immobility time in & $\mathrm{NE}$ \\
\hline & and $1 \mathrm{mg} / \mathrm{kg}$ & & rats $(n=6)$ & locomotor activity & FST; avoidance- & \\
\hline & (i.p.) & & & test & facilitator effect & \\
\hline \multirow[t]{3}{*}{ FG 7142} & 30 mg/kg (i.p.) & Acute & Male Sprague- & Measurement of $\mathrm{ACh}$ & $\uparrow$ hippocampal ACh & Activation of \\
\hline & & & Dawley rats & and NA release & and $\uparrow$ cortical NA & ACh and NA \\
\hline & & & (ND) & & & systems \\
\hline \multirow[t]{8}{*}{ Harman } & 5,10 and 20 & Acute & Male Sprague- & 5-HT perfusion in & $\uparrow 5$-HT and $\downarrow 5$-HIAA & MAO-A \\
\hline & $\mathrm{mg} / \mathrm{kg}$ (i.p. or & & Dawley rats & dorsal hippocampus & efflux in hippocampal & inhibition \\
\hline & hippocampus & & $(n=9-29)$ & & dialysates & \\
\hline & perfusion) & & & & & \\
\hline & $2.5,5$ and 10 & Acute & Male Sprague- & FST and EPM & $\downarrow$ immobility time in & $\mathrm{NE}$ \\
\hline & $\mathrm{mg} / \mathrm{kg}$ (i.p.) & & Dawley rats & & FST and $\uparrow$ time spent & \\
\hline & & & $(\mathrm{n}=10)$ & & in open arms during & \\
\hline & & & & & EPM test & \\
\hline
\end{tabular}




\begin{tabular}{|c|c|c|c|c|c|c|}
\hline 5 and 10 & Chronic & Male Wistar & CMS combined with & $\downarrow$ immobility time in & $\downarrow$ overexpression & [59] \\
\hline mg/kg (i.p.) & $\begin{array}{l}\text { (once a day, } \\
\text { during } 20 \\
\text { days) }\end{array}$ & $\begin{array}{l}\text { albino rats } \\
(\mathrm{n}=10-12)\end{array}$ & $\begin{array}{l}\text { FST, sucrose } \\
\text { preference test and } \\
\text { immunohistochemical } \\
\text { analysis }\end{array}$ & $\begin{array}{l}\text { FST and } \uparrow \text { sucrose } \\
\text { preference; } \\
\text { suppression of } \\
\text { microglial } \\
\text { neuroinflammation }\end{array}$ & of Iba-1 & \\
\hline $\begin{array}{l}\text { 5, } 10 \text { and } 15 \\
\mathrm{mg} / \mathrm{kg} \text { (i.p.) }\end{array}$ & Acute & $\begin{array}{l}\text { Male Swiss- } \\
\text { Webster mice } \\
(\mathrm{n}=7-8)\end{array}$ & 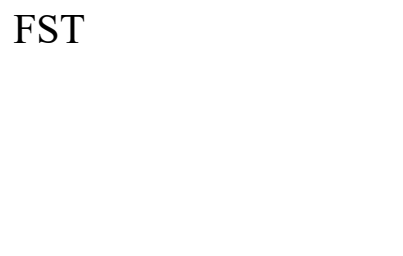 & $\downarrow$ immobility time & $\begin{array}{l}\text { Inverse agonist } \\
\text { of } \mathrm{GABA}_{\mathrm{A}} \\
\text { receptors }\end{array}$ & {$[60]$} \\
\hline $\begin{array}{l}2.5 \text { and } 10 \\
\mathrm{mg} / \mathrm{kg} \text { (i.p.) }\end{array}$ & Acute & $\begin{array}{l}\text { Male Sprague- } \\
\text { Dawley rats } \\
(\mathrm{n}=7-8)\end{array}$ & $\begin{array}{l}\text { Fear-conditioned test } \\
\text { combined with } \\
\text { biochemical analysis }\end{array}$ & $\begin{array}{l}\uparrow \mathrm{ACTH} \text { and } \\
\text { corticosterone } \\
\text { differential effects on } \\
\text { DA, NA and 5-HT } \\
\text { transmissions }\end{array}$ & $\begin{array}{l}\text { Involvement of } \\
\text { 5-HT, NA, DA } \\
\text { systems }\end{array}$ & [61] \\
\hline
\end{tabular}




\begin{tabular}{|c|c|c|c|c|}
\hline $\begin{array}{l}\text { 5, } 10 \text { and } 15 \\
\text { mg/kg (i.p.) }\end{array}$ & Acute & $\begin{array}{l}\text { Male Swiss- } \\
\text { Webster mice } \\
(\mathrm{n}=7-8)\end{array}$ & FST & $\downarrow$ immobility time \\
\hline $\begin{array}{l}\text { 5, } 10 \text { and } 15 \\
\text { mg/kg (i.p.) }\end{array}$ & Acute & $\begin{array}{l}\text { Male Wistar } \\
\text { rats }(n=15)\end{array}$ & $\begin{array}{l}\text { FST, OFT and } \\
\text { biochemical analysis }\end{array}$ & $\begin{array}{l}\downarrow \text { immobility time in } \\
\text { FST, } \uparrow \text { climbing and } \\
\text { swimming } \\
\text { Time }\end{array}$ \\
\hline $\begin{array}{l}\text { 5, } 10 \text { and } 15 \\
\text { mg/kg (i.p.) }\end{array}$ & $\begin{array}{l}\text { Chronic } \\
\text { (once a day, } \\
\text { during } 14 \\
\text { days) }\end{array}$ & $\begin{array}{l}\text { Male Wistar } \\
\text { rats }(n=15)\end{array}$ & $\begin{array}{l}\text { FST, OFT and } \\
\text { biochemical analysis }\end{array}$ & $\begin{array}{l}\downarrow \text { immobility time in } \\
\text { FST, } \uparrow \text { climbing and } \\
\text { swimming } \\
\text { Time }\end{array}$ \\
\hline 15 mg/kg (i.p.) & $\begin{array}{l}\text { Chronic } \\
\text { (once a day, } \\
\text { during } 7 \\
\text { days) }\end{array}$ & $\begin{array}{l}\text { Male Wistar } \\
\text { rats }(n=15)\end{array}$ & $\begin{array}{l}\text { CMS combined with } \\
\text { OFT and anhedonia } \\
\text { test; biochemical } \\
\text { analysis }\end{array}$ & $\downarrow$ anhedonia \\
\hline
\end{tabular}

Restoration of

[27]

BNDF and

ACTH levels 


\begin{tabular}{|c|c|c|c|c|c|c|}
\hline 10 and 20 & Chronic & Male C57BL/6J & CUS combined with & $\downarrow$ immobility time in & $\uparrow \mathrm{BDNF}, \mathrm{GFAP}$ & {$[62]$} \\
\hline $\mathrm{mg} / \mathrm{kg}$ (i.p.) & $\begin{array}{l}\text { (once a day, } \\
\text { during } 10 \\
\text { days) }\end{array}$ & mice $(n=10)$ & $\begin{array}{l}\text { TST, FST and } \\
\text { sucrose preference } \\
\text { test; Western blot and } \\
\text { immunofluorescence } \\
\text { analysis }\end{array}$ & $\begin{array}{l}\text { TST and FST, } \uparrow \\
\text { sucrose preference; } \\
\text { restoration of } \\
\text { astrocytic functions }\end{array}$ & and GLT-1 & \\
\hline $\begin{array}{l}2.5,5 \text { and } 10 \\
\text { mg/kg (i.p.) }\end{array}$ & Acute & $\begin{array}{l}\text { Male Swiss- } \\
\text { Webster mice } \\
(n=7-8)\end{array}$ & FST & $\downarrow$ immobility time & $\begin{array}{l}\text { Inverse agonist } \\
\text { of } \mathrm{GABA}_{\mathrm{A}} \\
\text { receptors }\end{array}$ & {$[60]$} \\
\hline $\begin{array}{l}2,8,15 \text { and } 20 \\
\text { mg/kg (i.p.) }\end{array}$ & Acute & $\begin{array}{l}\text { Male Wistar } \\
\text { rats }(n=8)\end{array}$ & FST, OFT and EPM & $\begin{array}{l}\downarrow \text { immobility time in } \\
\text { FST }\end{array}$ & $\mathrm{NE}$ & [63] \\
\hline $10 \mathrm{mg} / \mathrm{kg}$ (i.p.) & $\begin{array}{l}\text { Chronic } \\
\text { (once a day, } \\
\text { during } 10 \\
\text { days) }\end{array}$ & Rats* & $\begin{array}{l}\text { Citalopram } \\
\text { interaction test }\end{array}$ & $\begin{array}{l}\text { Competitive } \\
\text { interaction with } \\
\text { citalopram }\end{array}$ & $\begin{array}{l}\text { 5-HT reuptake } \\
\text { inhibition }\end{array}$ & [64] \\
\hline
\end{tabular}




Male NIH Inverted-screen test

Swiss and

C57B1/6 mice

$\begin{array}{ll}\downarrow \text { immobility time } & \text { Involvement of } \\ \text { when combined to } & \text { GABA }_{\mathrm{A}} \\ \text { diazepam treatment } & \text { receptors }\end{array}$

$\downarrow$ immobility time

(ND)

ND (not described). NE (not evaluated). *strain, gender and number of animals per group were not described. AAT (active avoidance test), ACh (acetylcholine), CMS (chronic mild stress), CUS (chronic unpredictable stress), DA (dopamine), DMCM (6,7-dimethoxy-4-ethyl- $\beta$-carboline methyl ester), EPM (elevated plusmaze test), FST (forced swimming test), GFAP (glial fibrillary acidic protein), GLT-1 (glutamate transporter-1), Iba-1 (ionizing calcium-binding adaptor molecule 1), MAO-A (monoamine oxidase-A), MAO-B (monoamine oxidase-B), NA (noradrenaline), OFT (open field test), TST (tail suspension test), $\beta$-CCM ( $\beta$ carboline-3-carboxylic acid methyl ester), $\beta$-CCT ( $\beta$-carboline-3-carboxylate-t-butyl ester). 


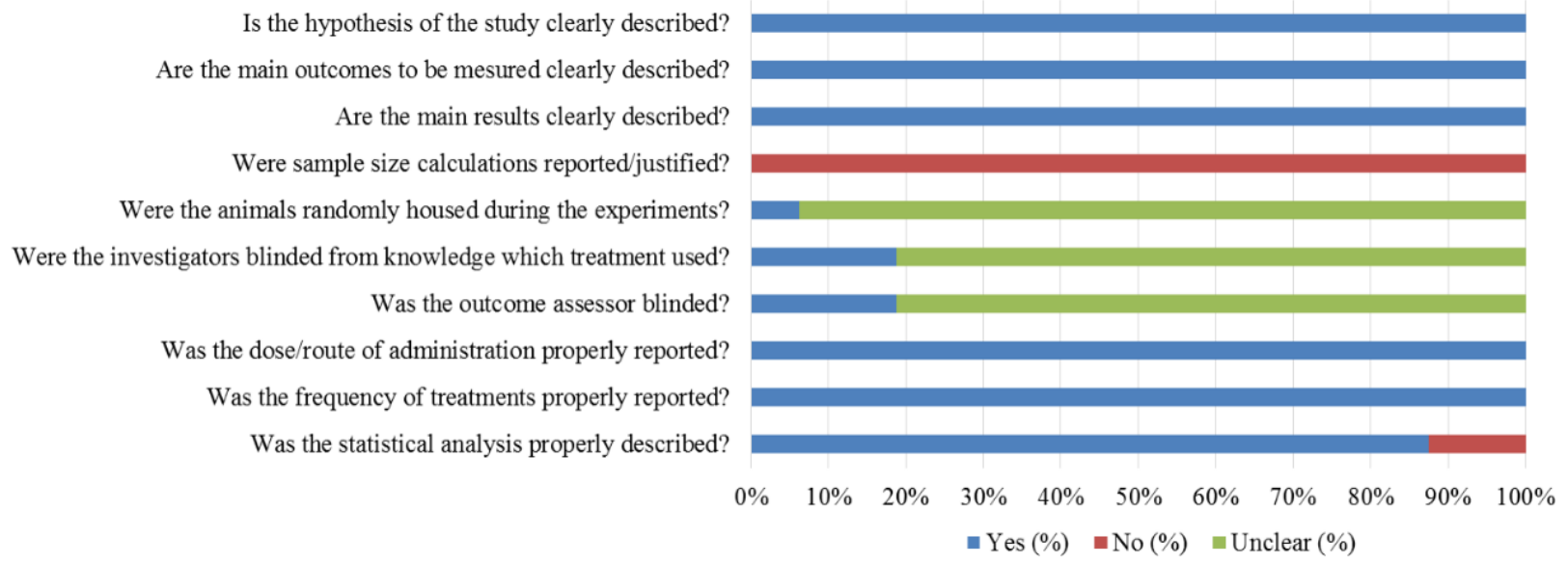

Fig. 7. Methodological quality assessment of in vivo studies included.

\subsection{Antidepressant effect of $\beta$-carbolines}

Although it has been investigated since a long time, the antidepressant effect of $\beta$ carboline alkaloids remains incompletely clarified. Many $\beta$-carbolines remain poorly exploited, limited by in vitro reports that do not perfectly reproduce the biochemical and physiological changes involved in depression disorders. However, a large part of the in vivo and in vitro studies is concentrated on two molecules (harman and harmine). These are endogenous alkaloids synthesized spontaneously via a condensation reaction of precursors such as tryptophan, tryptamine and serotonin with several carbonyls or ketoacids, particularly acetaldehyde or pyruvate $[60,66-69]$.

When administrated orally, both harman and harmine undergo first-pass metabolism. Overall, $\beta$-carbolines are efficiently metabolized by P450 enzymes, especially by the 1A2, 1A1, 2D6, 2E1, and 2C19 enzymatic complexes. The metabolic transformation pathways of these compounds include monohydroxylation, dihydroxylation, $\mathrm{N}$ methylation, $\mathrm{N}$-oxidation, $\mathrm{O}$-glucuronide conjugation, $\mathrm{O}$-sulphate and glutathione conjugation. Their specific metabolism have important implications for their distribution profile and consequently for their pharmacological and toxicological responses. 
Furthermore, it may cause significant interactions with other P450 substrates, such as antidepressant drugs that are also metabolized or bioactivated by the same enzymes $[69,70]$.

In contrast, after intravenous administration, harman and harmine are rapidly cleared from the blood [69]. Due to their high lipophilicity, brain concentrations are significantly higher than those in plasma, which certainly contributes to their CNS effects [58]. Indeed, they have been investigated in several animal models for depression conditions and some mechanisms of action have been proposed. Next, we present the main results found in this systematic review for both compounds.

\subsubsection{Harman}

Harman (syn. harmane) is a classic $\beta$-carboline, commonly found in a variety of medicinal plants and foods, including coffee, wine and sauces [22,23]. It is also present in tobacco smoke [24]. Furthermore, harman occurs in blood, heart, liver, urine and brain, and can influence several central neurotransmitter systems [29,71-73]. Previous reports have described harman as an atypical central-role compound [74], because of its broad CNS performance, acting differently depending on the doses and experimental protocols used. Harman has shown anticonvulsant (at low doses), pro-convulsant (at high doses) [75,76], anxiolytic and antidepressant activities [58], besides acting on learning and memory in rats [77].

Regarding its antidepressant potential, harman have decreased depressive behaviors in animal models. Acute treatments $(2.5-15 \mathrm{mg} / \mathrm{kg}$, i.p.) reduced dose-dependently the time of immobility in the forced swimming test, compared to the control group $[58,60]$. Its antidepressant-like effect was completely antagonized by flumazenil injection $(5 \mathrm{mg} / \mathrm{kg}$, i.p., 30 min before treatment with harman), suggesting an antidepressant activity via an 
inverse-agonistic mechanism of BZ receptors [60]. However, the in vivo antidepressant activity of harman also involves monoaminergic system and neuroendocrine response. Smith et al. [61] showed that harman increases plasma ACTH and corticosterone levels, and 5-HT (in hypothalamus, amygdaloidal cortex, prefrontal cortex and hippocampus) and NA (prefrontal cortex) contents in fear-conditioned rats. In addition, localized perfusion of harman in dorsal hippocampus of freely moving rats increased the levels of 5-HT but not 5-HIAA (the primary metabolite of 5-HT) in cerebral dialysates. Similarly, systemic administrations of harman enhanced 5-HT in the perfusates, but reduced the levels of 5HIAA in a dose-dependent manner, indicating a possible MAO-A inhibitory activity [29]. Besides, harman binds directly to 5-HT receptors, especially 5- $\mathrm{HT}_{2 \mathrm{~A}}$. In contrast, in vitro assays have shown that harman has no relevant affinity for DA and BZ receptors [28].

\subsubsection{Harmine}

Harmine was first isolated in 1847 from seeds of Peganum harmala and Banisteriopsis caapi, both of which are traditionally used for ritual and medicinal preparations in the Middle East, Central Asia and South America [47,62,78]. These plants are often found in the composition of Ayahuasca, a hallucinogenic beverage rich in $\beta$ carboline alkaloids, including harmine [19]. This alkaloid is also present in common plantderived foods and in human tissues [79]. In past decades, a wide range of pharmacological activities of harmine have been revealed, such as antioxidant [80,81], antiplasmodial [82], antidiabetic [83], antiplatelet [84], antigenotoxic and antimutagenic [81] effects. Nevertheless, harmine has aroused interest primarily for its CNS properties, especially in depressive disorders. Recently, strong correlations between harmine and depression have been evidenced in depressed patients treated with a single dose of ayahuasca (harminecontaining preparation), producing rapid and sustained antidepressant-like activity $[85,86]$. 
Preclinical investigations have shown that harmine has potential antidepressant-like effects in acute and chronic depression models. Similarly to harman, acute treatment with harmine $(5-15 \mathrm{mg} / \mathrm{kg}$, i.p.) reduced the immobility time in the FST in a dose-dependent manner. This pharmacological response was completely antagonized by pre-treatment with flumazenil ( $5 \mathrm{mg} / \mathrm{kg}$, i.p.), indicating the involvement of an inverse-agonistic mechanism of $\mathrm{GABA}_{\mathrm{A}}$ receptors in the antidepressant-like effect of harmine [60]. Fortunato et al. [15] also demonstrated that harmine decreased immobility time and increased both swimming and climbing of animals in the FST, without affecting their spontaneous locomotor activity in the OFT. In this study, harmine at the higher dose $(15 \mathrm{mg} / \mathrm{kg})$ increased hippocampal BDNF (brain-derived neurotrophic factor) protein levels compared with saline group, detected immediately after the FST. In a later study, Fortunato et al. (2010a) showed that chronic treatment with harmine (5-15 mg/kg/day, i.p., during 14 days) reduced immobility time of animals in the FST at all doses tested, without affecting spontaneous locomotor activity in the OFT. BDNF hippocampal levels were investigated in imipramine and harmine-treated rats. Interestingly, chronic administration of harmine (10 and $15 \mathrm{mg} / \mathrm{kg})$, but not imipramine, increased BDNF levels, corroborating the previous study. These findings indicate that harmine could be a new pharmacological alternative for the treatment of mood disorders.

Behavioral and physiological effects of repeated treatment with harmine were also investigated in rats submitted to the chronic mild stress (CMS) procedure. Animals were exposed to 40 days of chronic unpredictable stressful stimuli, and afterwards sucrose consumption (anhedonia test), behavioral and endocrine parameters were assessed in saline- and harmine-treated rats (15 mg/kg/day, i.p., for 7 days). Chronic stressful situations induced anhedonia, hypertrophy of adrenal gland, increase ACTH circulating levels and hippocampal BDNF levels in saline-treated rats. In contrast, treatment with harmine 
reversed anhedonia and normalized adrenal gland weight, ACTH and BDNF levels, suggesting that its antidepressant activity involves not only a neurogenic mechanism, but also a neuroendocrine response [27].

In a recent study, Liu et al. [62] investigated the effects of harmine on chronic unpredictable stress (CUS) model and astrocytic dysfunction. Chronic treatment with harmine (10 and $20 \mathrm{mg} / \mathrm{kg}$ ) protected the animals against de CUS-induced increases in immobility time in the FST and TST, and reversed the reduction in sucrose intake during the sucrose preference test. Harmine prevented the decreases in BDNF levels and increased the expression of glutamate transporter-1 (GLT-1). Additionally, harmine prevented the CUS-induced decreases in glial fibrillary acidic protein (GFAP) expression in the prefrontal cortex and hippocampus, indicating that restoration of astrocytic functions may be a potential mechanisms underlying its antidepressant activity.

\subsubsection{Others $\beta$-carbolines}

Although harman and harmine are the main $\beta$-carbolines studied in depressive disorders, other alkaloids of this class have also been investigated. Treatments with norharman, pinoline, DMCM and $\beta$-CCT reduced the immobility time in the FST, suggesting an antidepressant-like activity $[56,60,63,65]$. Some of these molecules (norharman, DMCM and $\beta-\mathrm{CCT}$ ) have acted as inverse agonists of $\mathrm{GABA}_{\mathrm{A}}$ receptors, which justifies their pharmacological response. However, 6-methoxy-tetrahydronorharman and pinoline seem to interfere with the monoaminergic neurotransmission system. Pahkla et al. [64] has demonstrated that pinoline inhibits 5-HT reuptake, keeping the 5-HT levels in synaptic cleft longer. Complementarily, 6-methoxy-tetrahydronorharman increases the hippocampal 5-HT and NA levels probably due to inhibition of MAO, preferentially MAOA isoform [41]. 


\subsection{Molecular mechanisms}

Monoamine hypothesis is the major biochemical theory of depression disorders. Initially proposed in the 1950s [87], it explains depression as a consequence of an alteration in levels of one or more monoamines, including serotonin (5-HT), dopamine (DA) and noradrenaline (NA). CNS contains a large number of noradrenergic, serotoninergic and dopaminergic neurons. In general, NA modulates the function of prefrontal cortex, the processing of working memory and regulates behavior and attention. 5-HT is the largest cohesive neurotransmitter systems in the brain, playing an important role in regulating mood, emotion and motor activity. Hypo or hyperserotoninergic states may be involved in depressive behaviors, suggesting that this monoamine exerts a key role in balancing other neurotransmitters also involved in depression conditions. Finally, DA modulates motor coordination, reward and motivation functions, working memory and attention [88-92]. In

this sense, monoaminergic systems dysfunction can be responsible for many behavioral symptoms of depression, such as low mood, vigilance, reduced motivation, fatigue, aggression, impaired concentration and cognitive performance [88]. For this reason, most antidepressant medications work by increasing the levels of monoamines in the synaptic cleft and consequently modulating their respective neurotransmission systems.

Several studies have demonstrated that $\beta$-carbolines increase the extracellular levels of these monoamines in different brain regions via MAO inhibition $[29,37,40]$ and 5-HT reuptake inhibition [55]. Monoamine oxidases (MAOs) belong to the family of flavincontaining amine oxidoreductases, usually located within the outer mitochondrial membrane, and they catalyze the oxidative deamination of monoamines. There are two MAO isoforms, MAO-A and B, with different substrate specificity. MAO-A metabolizes preferentially 5-HT molecules, whereas MAO-B has a major affinity to phenylethylamine 
and benzylamine. DA and NA are normally metabolized for both isoforms $[93,94]$. Previous study showed that $\beta$-carbolines increases 5 -HT levels, probably due to their capacity to inhibit MAO-A preferentially [37,55]. Interestingly, these alkaloids are able to interact with several cell-surface receptors, including 5- $\mathrm{HT}_{2 \mathrm{~A}}$ receptors [28], which are related to antidepressant pharmacotherapy. 5- $\mathrm{HT}_{2 \mathrm{~A}}$ are Gq-protein coupled receptors present in various brain regions involved in emotionality, such as amygdala, hippocampus, thalamus and cortical areas. Once activated, these receptors may control neuronal excitability in most networks involved in depression through modulation of glutamatergic and GABAergic post-synaptic neurons, leading to antidepressant effects $[95,96]$.

In addition to serotoninergic receptors, $\beta$-carbolines also interact with $\mathrm{GABA}_{\mathrm{A}}$ receptors. In this case, animal models and binding in vitro assays have indicated that an inverse-agonistic mechanism is involved, reducing inhibitory post-synaptic signals and consequently modulating antidepressant-like effects of monoamines, such as 5-HT. This seems to be a complementary mechanism of action, since some carbolines act as inverse agonists of $\mathrm{GABA}_{\mathrm{A}}$ receptors and directly modulate the 5-HT system through inhibition of MAO-A and 5-HT reuptake [20,22,28,60].

Recently, some new molecular mechanisms have been proposed for the antidepressant activity of $\beta$-carbolines. Fortunato et al. $[15,27]$ have showed that acute and chronic treatments with $\beta$-carbolines increase hippocampal BDNF levels in animals. Neurotrophic factors, such as BDNF, have been reported as important regulators of the formation and plasticity of neural networks, playing a relevant role in mood disorders [97100]. Appropriate levels of BDNF are instrumental for survival, maintenance and growth of brain and peripheral neurons [101]. BDNF-mediated signaling is commonly involved in neuroplastic response to stress conditions and it is essential for antidepressant drug action $[98,102]$. Indeed, reduced brain BDNF levels have been detected in post-mortem samples 
from depressed patients [103]. In contrast, brain infusion of BDNF promotes antidepressant-like effects by interaction with BDNF-TrkB receptors [104]. Therefore, $\beta$ carbolines may stimulate hippocampal neurogenesis by increasing BDNF levels, leading to an antidepressant activity.

$\beta$-carbolines also promote antidepressant-like effects through neuroendocrine response and protection of astrocytic function. They are able to normalize ACTH and corticosterone levels, two important hormones involved in stressful conditions [61]. Liu et al. [62] have shown that $\beta$-carbolines produces antidepressant activity via restoration of astrocytic functions. Chronic treatment with one of the most studied $\beta$-carboline (harmine) upregulated GFAP and GLT-1 (glutamate transporter), relevant markers of astrocyte activity. Previous evidences have demonstrated that astrocytic dysfunction is actively involved in the pathogenesis of depression. Reduced numbers of hippocampal astrocytes have been observed in animals submitted to chronic stress or maternal deprivation [105]. In fact, astrocytic dysfunction prevent extracellular glutamate clearance, ultimately resulting in an altered synaptic glutamate content, which interferes in others neurotransmission systems and consequently contributes to the pathogenesis of depressive disorders $[106,107]$. In Fig. 8, we illustrate the main molecular mechanisms involved in the antidepressant-like effects of $\beta$-carbolines. 


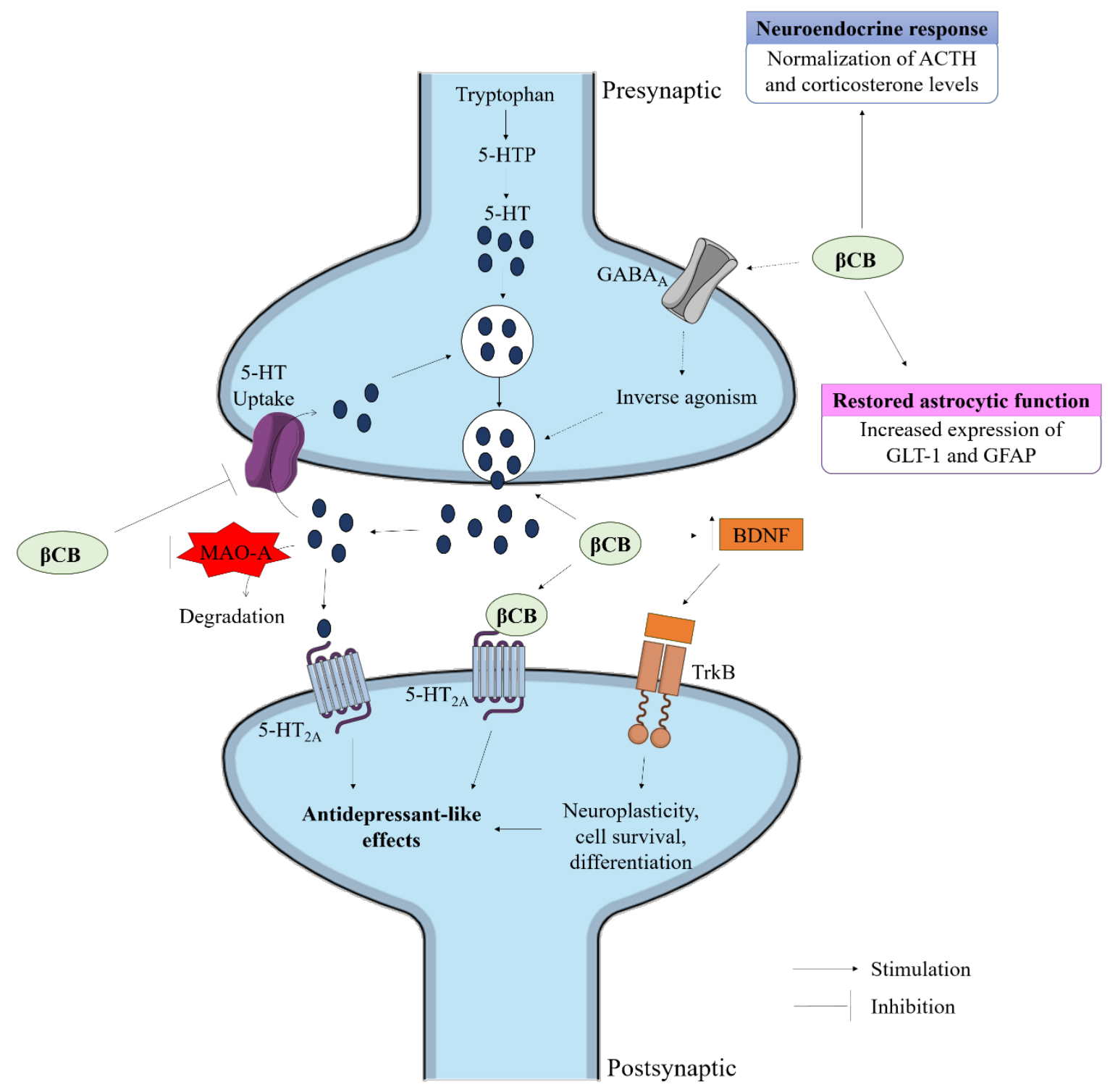

Fig. 8. Main molecular mechanisms involved in the antidepressant effects of $\beta$-carbolines $(\beta C B) . \beta C B$ increases 5-HT neurotransmission by inhibition of MAO-A, 5-HT reuptake and by acting on cell-surface receptors such as $5-\mathrm{HT}_{2 \mathrm{~A}}$ receptors. $\beta \mathrm{CB}$ acts on $\mathrm{GABA}_{\mathrm{A}}$ receptors as an inverse agonist, modulating others neurotransmission systems. $\beta C B$ induces higher expression of BDNF, assuring neuroplasticity, cell survival and differentiation mechanisms, which contributes to its antidepressant activity. Additionally, $\beta C B$ promotes neuroendocrine response (normalizing $\mathrm{ACTH}$ and corticosterone levels) and restore astrocytic function (increasing the expression of GLT-1 and GFAP). 


\section{Conclusion}

This systematic review summarized the pre-clinical findings involving the use of $\beta$-carboline alkaloids with antidepressant potential. In vitro and in vivo reports have demonstrated that a variety of $\beta$-carbolines have been investigated for antidepressant purposes, but most of the studies remains superficial, without employing well-delineated experimental models or providing further details on the molecular mechanisms involved in the pharmacological effects described. However, two molecules have been extensively studied in depression models: harman and harmine. These $\beta$-carbolines were effective when administrated acutely or chronically in different animal protocols, including chronic mild stress models. The diversity of proposed mechanisms of action for these compounds suggests that they are multi-target drugs and may be useful in the treatment of depressive disorders.

\section{ACKNOWLEDGEMENTS}

The authors thank to CAPES (Coordenação de Aperfeiçoamento de Pessoal de Nível Superior) funding CAAF’s PhD grant.

\section{CONFLICT OF INTEREST}

The authors declare that they have no conflict of interest.

\section{REFERENCES}

[1] D.P. Chapman, G.S. Perry, Depression as a Major Component of Public Health for Older Adults, Prev Chronic Dis. 5 (2008) 1-9.

[2] P.W. Gold, R. Machado-vieira, M.G. Pavlatou, Clinical and Biochemical 
Manifestations of Depression: Relation to the Neurobiology of Stress, Neural Plast. 2015 (2015) 7-9. doi:10.1155/2015/581976.

[3] D. Richards, Clinical Psychology Review Prevalence and clinical course of depression: A review, Clin. Psychol. Rev. 31 (2011) 1117-1125. doi:10.1016/j.cpr.2011.07.004.

[4] J. Wang, X. Wu, W. Lai, E. Long, X. Zhang, W. Li, Y. Zhu, C. Chen, X. Zhong, Z. Liu, D. Wang, H. Lin, Prevalence of depression and depressive symptoms among outpatients: a systematic review and meta-analysis, BMJ Open. 7 (2017) e017173. doi:10.1136/bmjopen-2017-017173.

[5] R.C. Kessler, E.J. Bromet, The Epidemiology of Depression Across Cultures, Clin. Rev. Educ. 317 (2017) 2114-2122. doi:10.1146/annurev-publhealth-031912114409.

[6] P. Belujon, A.A. Grace, Dopamine System Dysregulation in Major Depressive Disorders, Int. J. Neuropsychopharmacol. 20 (2017) 1036-1046. doi:10.1093/ijnp/pyx056.

[7] P.R. Albert, C. Benkelfat, P.R. Albert, L. Descarries, The neurobiology of depression - revisiting the serotonin hypothesis. II Genetic , epigenetic and clinical studies, Philos. Trans. R. Soc. B. 368 (2013) 3-6.

[8] C. Moret, M. Briley, The importance of norepinephrine in depression, Neuropsychiatr. Dis. Treat. 7 (2011) 9-13. doi:10.2147/NDT.S19619.

[9] P.J. Cowen, M. Browning, What has serotonin to do with depression?, World Psychiatr. 14 (2015) 11-13. doi:10.1002/wps.20229.

[10] A. Cipriani, T.A. Furukawa, G. Salanti, A. Chaimani, L.Z. Atkinson, Y. Ogawa, S. Leucht, H.G. Ruhe, J.P.A. Ioannidis, J.R. Geddes, Comparative efficacy and acceptability of 21 antidepressant drugs for the acute treatment of adults with 
major depressive disorder : a systematic review and network meta-analysis, Lancet. 391 (2018) 1357-1366. doi:10.1016/S0140-6736(17)32802-7.

[11] G. Gartlehner, G. Wagner, N. Matyas, V. Titscher, J. Greimel, L. Lux, B.N. Gaynes, M. Viswanathan, S. Patel, K.N. Lohr, Pharmacological and nonpharmacological treatments for major depressive disorder: review of systematic reviews, BMJ Open. 7 (2017) 1-13. doi:10.1136/bmjopen-2016-014912.

[12] E. Penn, D.K. Tracy, The drugs don't work? antidepressants and the current and future pharmacological management of depression, Ther. Adv. Psychopharmacol. 2 (2012) 179-188. doi:10.1177/2045125312445469.

[13] P.K. Gillman, Tricyclic antidepressant pharmacology and therapeutic drug interactions updated, Br. J. Pharmacol. 151 (2007) 737-748. doi:10.1038/sj.bjp.0707253.

[14] D.J. McKenna, G.H.N. Towers, F. Abbott, Monoamine oxidase inhibitors in South American hallucinogenic plants: tryptamine and b-carboline constituents of Ayahuasca, J. Ethnopharmocology. 10 (1984) 195-223.

[15] J.J. Fortunato, G.Z. Réus, T.R. Kirsch, R.B. Stringari, L. Stertz, F. Kapczinski, J.P. Pinto, J.E. Hallak, A.W. Zuardi, J.A. Crippa, J. Quevedo, Acute harmine administration induces antidepressive-like effects and increases BDNF levels in the rat hippocampus, Prog. Neuropsychopharmacol. Biol. Psychiatry. 33 (2009) 1425-1430. doi:10.1016/j.pnpbp.2009.07.021.

[16] P. Heshmati, M. Nasehi, M.R. Zarrindast, An overview of cognitive aspects of $\beta$ carbolines, J. Paramed. Sci. 5 (2014) 99-104.

[17] R. Cao, W. Peng, Z. Wang, A. Xu, Beta-Carboline Alkaloids : Biochemical and Pharmacological Functions, Curr. Med. Chem. 14 (2007) 479-500.

[18] M.C. Niroumand, M.H. Farzaei, G. Amin, Medicinal properties of Peganum 
harmala L. in traditional Iranian medicine and modern phytotherapy: a review, J. Tradit. Chinese Med. 35 (2015) 104-109. doi:10.1016/S0254-6272(15)30016-9.

[19] E. Frecska, P. Bokor, M. Winkelman, The Therapeutic Potentials of Ayahuasca: Possible Effects against Various Diseases of Civilization, Front. Pharmacol. 7 (2016) 1-17. doi:10.3389/fphar.2016.00035.

[20] T. Herraiz, D. González, C. Ancín-azpilicueta, V.J. Arán, H. Guillén, b-Carboline alkaloids in Peganum harmala and inhibition of human monoamine oxidase (MAO), Food Chem. Toxicol. 48 (2010) 839-845. doi:10.1016/j.fct.2009.12.019.

[21] M. Moloudizargari, P. Mikaili, S. Aghajanshakeri, M.H. Asghari, J. Shayegh, Pharmacological and therapeutic effects of Peganum harmala and its main alkaloids, Pharmacogn. Rev. 7 (2019) 199-212. doi:10.4103/0973-7847.120524.

[22] T. Herraiz, C. Chaparro, Human monoamine oxidase enzyme inhibition by coffee and b-carbolines norharman and harman isolated from coffee, Life Sci. 78 (2006) 795-802. doi:10.1016/j.lfs.2005.05.074.

[23] T. Herraiz, Identification and Occurrence of -Carboline Alkaloids in Raisins and Inhibition of Monoamine Oxidase (MAO), J. Agric. Food Chem. 55 (2007) 85348540.

[24] T. Herraiz, C. Chaparro, Human monoamine oxidase is inhibited by tobacco smoke: b-carboline alkaloids act as potent and reversible inhibitors, Biochem. Biophys. Res. Commun. 326 (2005) 378-386. doi:10.1016/j.bbrc.2004.11.033.

[25] F. Palhano-fontes, D. Barreto, H. Onias, K.C. Andrade, M.M. Novaes, J.A. Pessoa, S.A. Mota-rolim, F.L. Osório, R. Sanches, R.G. Santos, L.F. Tófoli, G.D.O. Silveira, M. Yonamine, J. Riba, F.R. Santos, A.A. Silva-junior, J.C. Alchieri, N.L. Galvão-coelho, B. Lobão-soares, D.B. Araújo, Rapid antidepressant effects of the psychedelic ayahuasca in treatment-resistant depression: a randomized placebo- 
controlled trial, Psychol. Med. 18 (2019) 4-12. doi:10.1017/S0033291718001356.

[26] M. V Uthaug, K. Van Oorsouw, K.P.C. Kuypers, M. Van Boxtel, N.J. Broers, N.L. Mason, S.W. Toennes, Sub-acute and long-term effects of ayahuasca on affect and cognitive thinking style and their association with ego dissolution, Psychopharmacology (Berl). 235 (2018) 2979-2989. doi:10.1007/s00213-0184988-3.

[27] J.J. Fortunato, G.Z. Réus, T.R. Kirsch, R.B. Stringari, G.R. Fries, F. Kapczinski, J.E. Hallak, A.W. Zuardi, J.A. Crippa, J. Quevedo, Effects of beta-carboline harmine on behavioral and physiological parameters observed in the chronic mild stress model: Further evidence of antidepressant properties, Brain Res. Bull. 81 (2010) 491-496. doi:10.1016/j.brainresbull.2009.09.008.

[28] R.A. Glennon, M. Dukat, B. Grella, S. Hong, L. Costantino, M. Teitler, C. Smith, C. Egan, K. Davis, M. V Mattson, Binding of b-carbolines and related agents at serotonin (5-HT2 and 5-HT 1A), dopamine (D2) and benzodiazepine receptors, Drug Alcohol Depend. 60 (2000) 121-132.

[29] A. Adell, T.A. Biggs, R.D. Myers, Action of Harman (1-methyl-P-carboline) on the Brain: Body Temperature and In Viva Efflux of 5-HT from Hippocampus of the Rat, Neuropharmacology. 35 (1996) 1101-1107.

[30] D. Moher, A. Liberati, J. Tetzlaff, D.G. Altman, T.P. Group, Preferred Reporting Items for Systematic Reviews and Meta-Analyses : The PRISMA Statement, Plos Med. 6 (2009) e1000097. doi:10.1371/journal.pmed.1000097.

[31] C.R. Hooijmans, M.M. Rovers, R.B.M. De Vries, M. Leenaars, M. Ritskeshoitinga, M.W. Langendam, SYRCLE' s risk of bias tool for animal studies, BMC Med. Res. Methodol. 14 (2014) 1-9. doi:10.1186/1471-2288-14-43.

[32] R.G. de Oliveira Júnior, A.F. Christiane Adrielly, J.R.G. da Silva Almeida, R. 
Grougnet, V. Thiéry, L. Picot, Sensitization of tumor cells to chemotherapy by natural products: A systematic review of preclinical data and molecular mechanisms, Fitoterapia. 129 (2018) 383-400. doi:10.1016/j.fitote.2018.02.025.

[33] S.K. Al-nuaimi, E.M. Mackenzie, G.B. Baker, Monoamine Oxidase Inhibitors and Neuroprotection : A Review, Am. J. Ther. 448 (2012) 436-448. doi:10.1097/MJT.0b013e31825b9eb5.

[34] M.B.H. Youdim, D. Edmondson, K.F. Tipton, The therapeutic potential of monoamine oxidase inhibitors, Nat. Rev. 7 (2006) 295-309. doi:10.1038/nrn1883.

[35] K.I. Shulman, N. Herrmann, S.E. Walker, Current Place of Monoamine Oxidase Inhibitors in the Treatment of Depression, CNS Drugs. 27 (2013) 789-797. doi:10.1007/s40263-013-0097-3.

[36] T. Herraiz, A. Flores, L. Fernández, Analysis of monoamine oxidase (MAO) enzymatic activity by high-performance liquid chromatography-diode array detection combined with an assay of oxidation with a peroxidase and its application to MAO inhibitors from foods and plants, J. Chromatogr. B. 1073 (2018) 136-144. doi:10.1016/j.jchromb.2017.12.004.

[37] H. Kim, S.O. Sablin, R.R. Ramsay, Inhibition of Monoamine Oxidase A by bCarboline Derivatives, Arch. Biochem. Biophys. 337 (1997) 137-142.

[38] T. May, H. Rommelspacher, M. Pawlik, [3H] Harman Binding Experiments. I: A Reversible and Selective Radioligand for Monoamine Oxidase Subtype A in the CNS of the Rat, J. Neurochem. 56 (1991) 490-499.

[39] T. May, M. Pawlik, H. Rommelspacher, Subcellular Distribution of Specific [3H] Harman Binding and Monoamine Oxidase Subtypes A and B Activity in Marmoset and Rat, J. Neurochem. 56 (1991) 500-508.

[40] A.F. Arriba, J.N. Lizcano, M.D. Balsa, M. Unzeta, Inhibition of Monoamine 
Oxidase from Bovine Retina by b-Carbolines, J. Pharm. Pharmacol. 46 (1994) 809-813.

[41] D.L. Sparks, N.S. Buckholtz, 6-Methoxy-1,2,3,4-tetrahydro-beta-carboline: a specific monoamine oxidase-A inhibitor in CF-1 mouse brain, Neurosci. Lett. 20 (1980) 73-78.

[42] F. Borsini, A. Meli, Psychopharmacology Is the forced swimming test a suitable model for revealing antidepressant activity?, Psychopharmacology (Berl). 94 (1988) 147-160.

[43] A. Can, D.T. Dao, M. Arad, C.E. Terrillion, S.C. Piantadosi, T.D. Gould, The Mouse Forced Swim Test, J. Vis. Exp. 59 (2012) 4-8. doi:10.3791/3638.

[44] R. Yankelevitch-Yahav, M. Franko, A. Huly, R. Doron, The Forced Swim Test as a Model of Depressive-like Behavior, J. Vis. Exp. 97 (2015) 1-7. doi:10.3791/52587.

[45] P. Willner, Neurobiology of Stress The chronic mild stress ( CMS ) model of depression: History , evaluation and usage, Neurobiol. Stress. 6 (2017) 78-93. doi:10.1016/j.ynstr.2016.08.002.

[46] P. Willner, Neurobiology of Stress Reliability of the chronic mild stress model of depression: A user survey, Neurobiol. Stress. 6 (2017) 68-77. doi:10.1016/j.ynstr.2016.08.001.

[47] J.J. Fortunato, G.Z. Reus, T.R. Kirsch, R.B. Stringari, G.R. Fries, F. Kapczinski, J.E. Hallak, A.W. Zuardi, J.A. Crippa, J. Quevedo, Chronic administration of harmine elicits antidepressant-like effects and increases BDNF levels in rat hippocampus, J. Neural Transm. 2010 (2010) 1131-1137. doi:10.1007/s00702010-0451-2.

[48] M.F.W. Festing, Design and Statistical Methods in Studies Using Animal Models 
of Development, ILAR J. 47 (2006) 5-14.

[49] J.A. Hirst, J. Howick, J.K. Aronson, N. Roberts, R. Perera, C. Koshiaris, C. Heneghan, The Need for Randomization in Animal Trials: An Overview of Systematic Reviews, PLoS One. 9 (2014) e98856.

doi:10.1371/journal.pone.0098856.

[50] P.J. Karanicolas, F. Farrokhyar, M. Bhandari, Blinding: Who, what, when, why, how?, Can. J. Surg. 53 (2010) 345-348.

[51] J.E. De Aguilar-Nascimento, Fundamental steps in experimental design for animal studies, Acta Cirúrgica Bras. 20 (2005) 2-8.

[52] T. Denayer, T. Stöhr, M. Van Roy, Animal models in translational medicine: Validation and prediction, New Horizons Transl. Med. 2 (2014) 5-11. doi:10.1016/j.nhtm.2014.08.001.

[53] C. Belzung, Innovative Drugs to Treat Depression: Did Animal Models Fail to Be Predictive or Did Clinical Trials Fail to Detect Effects?, Neuropsychopharmacology. 39 (2014) 1041-1051. doi:10.1038/npp.2013.342.

[54] R. Machado-vieira, Tracking the impact of translational research in psychiatry: state of the art and perspectives, J. Transl. Med. 10 (2012) 1. doi:10.1186/14795876-10-175.

[55] W.M. McIsaac, D. Taylor, K.E. Walker, B.T. Ho, 6-Methoxy-1,2,3,4-tetrahydro-bcarboline, a serotonin elevator, J. Neurochem. 19 (1972) 1203-1206.

[56] J. Samardžić, D.Š. Strac, M. Obradović, D. Oprić, D.I. Obradović, DMCM, a benzodiazepine site inverse agonist, improves active avoidance and motivation in the rat, Behav. Brain Res. 235 (2012) 195-199. doi:10.1016/j.bbr.2012.07.032.

[57] Y. Claustre, L. Rouquier, C. Desvignes, M. Leonetti, N. Aubin, N. Allouard, I. Bougault, R. Steinberg, Effects of the vasopressin (V1b) receptor antagonist, 
SSR149415, and the corticotropin-releasing factor 1 receptor antagonist, SSR125543, on FG 7142-induced increase in acetylcholine and norepinephrine release in the rat, Neuroscience. 141 (2006) 1481-1488. doi:10.1016/j.neuroscience.2006.05.006.

[58] F. Aricioglu, H. Altunbas, Harmane induces anxiolysis and antidepressant-like effects in rats, Ann. N. Y. Acad. Sci. 1009 (2003) 196-201. doi:10.1196/annals.1304.024.

[59] F. Aricioglu, G. Arkan, C. Kandemir, S. Sirvanci, C. Ozkartal, T. Utkan, Harmane suppresses microglial neuroinflammatory response and induce antidepressant-like effect in rats, Eur. Psychiatry. 415 (2017) S366-S404. doi:10.1016/j.eurpsy.2017.02.368.

[60] D. Farzin, N. Mansouri, Antidepressant-like effect of harmane and other bcarbolines in the mouse forced swim test, Eur. Neuropsychopharmacol. 16 (2006) 324-328. doi:10.1016/j.euroneuro.2005.08.005.

[61] K.L. Smith, G.K. Ford, D.S. Jessop, D.P. Finn, Behavioural, neurochemical and neuroendocrine effects of the endogenous $\beta$-carboline harmane in fear-conditioned rats, J. Psychopharmacol. 27 (2013) 162-170. doi:10.1177/0269881112460108.

[62] F. Liu, J. Wu, Y. Gong, P. Wang, L. Zhu, L. Tong, X. Chen, Y. Ling, C. Huang, Harmine produces antidepressant-like effects via restoration of astrocytic functions, Prog. Neuropsychopharmacol. Biol. Psychiatry. 79 (2017) 258-267. doi:10.1016/j.pnpbp.2017.06.012.

[63] R. Pahkla, J. Harro, L. Rago, Behavioural effects of pinoline in the rat forced swimming, open field and elevated plus-maze tests, Pharmacol. Res. 34 (1996) 7378.

[64] R. Pahkla, L. Rago, J.J. Callaway, M.M. Airaksinen, Binding of Pinoline on the 5- 
Hydroxytryptamine Transporter: Competitive Interaction with [3H] Citalopram, Pharmacol. Toxicol. 80 (1996) 122-126.

[65] K.R. Methuku, X. Li, R. Cerne, S.D. Gleason, J.M. Schkeryantz, V.V.N.P.B. Tiruveedhula, An antidepressant-related pharmacological signature for positive allosteric modulators of $\alpha 2 / 3$-containing GABAA receptors, Pharmacol. Biochem. Behav. 170 (2018) 9-13. doi:10.1016/j.pbb.2018.04.009.

[66] J. Moncrieff, Determination of pharmacological levels of harmane, harmine and harmaline in mammalian brain tissue, cerebrospinal fluid and plasma by highperformance liquid chromatography with fluorimetric detection, J. Chromatogr. B Biomed. Sci. Appl. 496 (1989) 269-278.

[67] M.J. Schouten, J. Bruinvels, Endogenously Formed Norharman (B-Carboline) in Platelet Rich Plasma Obtained From Porphyric Rats, Pharmacol. Toxicol. 24 (1986) 1219-1223.

[68] H. Rommelspacher, T. May, R. Susilo, B-carbolines and tetrahydroisoquinolines: Detection and Function in Mammals, Planta Med. 57 (1991) 85-92.

[69] S. Iuliana, R. Aro, B. Kiss, M. Manto, P. Duez, The Role of $\beta$-Carboline Alkaloids in the Pathogenesis of Essential Tremor, Cerebellum. 15 (2015) 276-284. doi:10.1007/s12311-015-0751-z.

[70] H. Guille, V.J. Ara, Oxidative Metabolism of the Bioactive and Naturally Occurring Carboline Alkaloids, Norharman and Harman, by Human Cytochrome P450 Enzymes, Chem. Res. Toxicol. 21 (2008) 2172-2180.

[71] O. Beck, K.F. Faull, Concentrations of the enantiomers of 5-hydroxymethtryptolne implications for in uivo biosynthesis in mammalian urine :, Biochem. Pharmacol. 435 (2011) 2636-2639.

[72] D.W. Shoemaker, J.T. Cummins, T.G. Bidder, H.G. Boetgger, M. Evans, 
Identification of Harman in the Rat Arcuate Nucleus, Naunyn. Schmiedebergs. Arch. Pharmacol. 230 (1980) 227-230.

[73] T.R. Bosin, S. Borg, K.F. Faull, Harman in Rat Brain, Lung and Human CSF: Effect of Alcohol Consumption, Alcohol. 5 (1989) 505-511.

[74] H. Abu, M.D. Lalies, D.J. Nutt, A.L. Hudson, Harmane: An atypical neurotransmitter?, Neurosci. Lett. 590 (2015) 1-5. doi:10.1016/j.neulet.2015.01.057.

[75] J.A. Fuentes, V.G. Longo, An investigation on the central effects of harmine, harmaline and related B-carbolines, Neuropharmacology. 10 (1971) 15-23.

[76] F. Aricioglu, O. Yillar, E. Korcegez, K. Berkman, Effect of Harmane on the Convulsive Threshold in Epilepsy Models in Mice, Ann. N. Y. Acad. Sci. 1009 (2003) 190-195. doi:10.1196/annals.1304.023.

[77] I. Komsuoglu, T. Utkan, S. Selcen, A. Hudson, F. Aricioglu, Effect of harmane, an endogenous $\beta$-carboline, on learning and memory in rats, Pharmacol. Biochem. Behav. 103 (2013) 666-671. doi:10.1016/j.pbb.2012.10.011.

[78] T.L. Sourkes, "Rational hope" in the early treatment of Parkinson's disease, Can J. Physiol. Pharmacol. 77 (1999) 62-63.

[79] Y. Guan, E.D. Louis, W. Zheng, Toxicokinetics of tremorogenic natural products, harmane and harmine, in male Sprague-Dawley rats, J. Toxicol. Environ. Health. 64 (2001) 645-660. doi:10.1080/152873901753246241.TOXICOKINETICS.

[80] D.H. Kim, Y.Y. Jang, E.S. Han, C.S. Lee, Protective effect of harmaline and harmalol against dopamine- and 6-hydroxydopamine-induced oxidative damage of brain mitochondria and synaptosomes, and viability loss of PC12 cells, Eur. J. Neurosci. 13 (2001) 1861-1872.

[81] D.J. Moura, M. Franc, A. Pe, M. Boeira, J. Saffi, Antioxidant properties of b- 
carboline alkaloids are related to their antimutagenic and antigenotoxic activities, Mutagenesis. 22 (2007) 293-302. doi:10.1093/mutage/gem016.

[82] A. Astulla, Æ.K. Zaima, Æ.Y. Matsuno, Y. Hirasawa, Æ.W. Ekasari, Æ.A. Widyawaruyanti, Alkaloids from the seeds of Peganum harmala showing antiplasmodial and vasorelaxant activities, J. Nat. Med. 62 (2008) 470-472. doi:10.1007/s11418-008-0259-7.

[83] H. Waki, K.W. Park, N. Mitro, L. Pei, R. Damoiseaux, D.C. Wilpitz, K. Reue, E. Saez, P. Tontonoz, The Small Molecule Harmine Is an Antidiabetic Cell-TypeSpecific Regulator of PPAR g Expression, Cell Metab. 5 (2007) 357-370. doi:10.1016/j.cmet.2007.03.010.

[84] J. Im, Y. Jin, J. Lee, J. Yu, X. Han, S. Im, J. Tae, H. Yoo, M. Pyo, Y. Yun, Antiplatelet activity of $\beta$-carboline alkaloids from Perganum harmala: A possible mechanism through inhibiting PLC $\gamma 2$ phosphorylation, Vascul. Pharmacol. 50 (2009) 147-152. doi:10.1016/j.vph.2008.11.008.

[85] F. de L. Osório, R.F. Sanches, L.R. Macedo, R.G. Santos, P.M. Oliveira, L. Wichert-Ana, D.B. De Araujo, J. Riba, A. Crippa, J.E. Hallak, Antidepressant effects of a single dose of ayahuasca in patients with recurrent depression: a preliminary report, Rev. Bras. Psiquiatr. 37 (2015) 13-20. doi:10.1590/1516-44462014-1496.

[86] R.F. Sanches, F.D.L. Osório, R.G. Santos, L.R.H. Macedo, J.P. Maia-de-oliveira, L. Wichert-ana, D.B. De Araujo, J. Riba, Antidepressant Effects of a Single Dose of Ayahuasca in Patients With Recurrent Depression, J. Clin. Psychopharmacol. 36 (2016) 77-81. doi:10.1097/JCP.0000000000000436.

[87] E.D. Freis, Mental Depression in Hypertensive Patients Treated for Long Periods with Large Doses of Reserpine, N. Engl. J. Med. 251 (1954) 1006-1008. 
doi:10.1056/NEJM195412162512504.

[88] E. Jesulola, P. Micalos, I.J. Baguley, Understanding the pathophysiology of depression : From monoamines to the neurogenesis hypothesis model - are we there yet ?, Behav. Brain Res. 341 (2018) 79-90. doi:10.1016/j.bbr.2017.12.025.

[89] M. Hamon, P. Blier, Monoamine neurocircuitry in depression and strategies for new treatments, Prog. Neuropsychopharmacol. Biol. Psychiatry. 45 (2013) 54-63. doi:10.1016/j.pnpbp.2013.04.009.

[90] C. Belzung, P. Willner, P. Philippot, Depression: from psychopathology to pathophysiology, Curr. Opin. Neurobiol. 30 (2015) 24-30. doi:10.1016/j.conb.2014.08.013.

[91] J. Dean, M. Keshavan, The neurobiology of depression: An integrated view, Asian J. Psychiatr. 27 (2018) 101-111. doi:10.1016/j.ajp.2017.01.025.

[92] J.S. Goldberg, C.E.B. Jr, D.A. Pollard, Revisiting the Monoamine Hypothesis of Depression: A New Perspective, Perspect. Medicin. Chem. (2014) 1-8. doi:10.4137/PMC.S11375.Academic.

[93] Z. Fišar, Drugs related to monoamine oxidase activity, Prog. Neuropsychopharmacol. Biol. Psychiatry. 69 (2016) 112-124. doi:10.1016/j.pnpbp.2016.02.012.

[94] S. Corbineau, M. Breton, J. Mialet-perez, J. Costemale-lacoste, Major depression and heart failure: Interest of monoamine oxidase inhibitors, Int. J. Cardiol. 247 (2017) 1-6. doi:10.1016/j.ijcard.2017.07.005.

[95] B.P. Guiard, G. Di Giovanni, Central serotonin-2A (5-HT2A) receptor dysfunction in depression and epilepsy: the missing link?, Front. Pharmacol. 6 (2015) 1-17. doi:10.3389/fphar.2015.00046.

[96] P. Celada, M.V. Puig, M. Amargós-bosch, A. Adell, F. Artigas, The therapeutic 
role of 5-HT1A and 5-HT2A receptors in depression, J. Psychiatry Neurosci. 29 (2004) 252-265.

[97] E.J. Huang, L. Reichardt, Neurotrophins: Roles in Neuronal Development and Function, Annu. Rev. Neurosci. 24 (2001) 677-736. doi:10.1146/annurev.neuro.24.1.677.Neurotrophins.

[98] E. Castrén, V. Voikar, T. Rantamaki, Role of neurotrophic factors in depression, Curr. Opin. Pharmacol. 7 (2007) 18-21. doi:10.1016/j.coph.2006.08.009.

[99] R.S. Duman, L.M. Monteggia, A Neurotrophic Model for Stress-Related Mood Disorders, Biol. Psychiatry. 59 (2006) 1116-1127. doi:10.1016/j.biopsych.2006.02.013.

[100] L.M. Monteggia, M. Barrot, C.M. Powell, O. Berton, V. Galanis, T. Gemelli, S. Meuth, A. Nagy, R.W. Greene, E.J. Nestler, Essential role of brain-derived neurotrophic factor in adult hippocampal function, Proc. Natl. Acad. Sci. U. S. A. 101 (2004) 10827-10832.

[101] R. Gary, Y. Barde, Physiology of neurotrophins, Annu. Rev. Neurosci. 19 (1996) $289-317$.

[102] V. Krishnan, E.J. Nestler, The molecular neurobiology of depression, Nature. 455 (2008) 894-902. doi:10.1038/nature07455.The.

[103] F. Karege, G. Vaudan, M. Schwald, N. Perroud, R. La Harpe, Neurotrophin levels in postmortem brains of suicide victims and the effects of antemortem diagnosis and psychotropic drugs, Mol. Brain Res. 136 (2005) 29-37. doi:10.1016/j.molbrainres.2004.12.020.

[104] M.E. Kozisek, D. Middlemas, D.B. Bylund, Brain-derived neurotrophic factor and its receptor tropomyosin-related kinase B in the mechanism of action of antidepressant therapies, Pharmacol. Ther. 117 (2008) 30-51. 
doi:10.1016/j.pharmthera.2007.07.001.

[105] M. Leventopoulos, D. Rüedi-bettschen, I. Knuesel, J. Feldon, C.R. Pryce, J. Opacka-juffry, Long-term effects of early life deprivation on brain glia in Fischer rats, Brain Res. 1142 (2007) 119-126. doi:10.1016/j.brainres.2007.01.039.

[106] S. Olivera-Bravo, A. Fernández, M.N. Sarlabós, J.C. Rosillo, G. Casanova, M. Jiménez, L. Barbeito, Neonatal Astrocyte Damage Is Sufficient to Trigger Progressive Striatal Degeneration in a Rat Model of, PLoS One. 6 (2011) 1-10. doi:10.1371/journal.pone.0020831.

[107] B. Schreiner, E. Romanelli, F. Heppner, Astrocyte Depletion Impairs Redox Homeostasis and Triggers Neuronal Loss in the Adult CNS Report Astrocyte Depletion Impairs Redox Homeostasis and Triggers Neuronal Loss in the Adult CNS, Cell Rep. 12 (2015) 1377-1384. doi:10.1016/j.celrep.2015.07.051. 